\title{
PPARy activation but not PPARy haplodeficiency affects proangiogenic potential of endothelial cells and bone marrow-derived progenitors
}

Jerzy Kotlinowski', Anna Grochot-Przeczek', Hevidar Taha', Magdalena Kozakowska', Bartosz Pilecki', Klaudia Skrzypek', Aleksandra Bartelik ${ }^{2,9}$, Rafal Derlacz ${ }^{3,4}$, Anton J G Horrevoets ${ }^{5}$, Attila Pap ${ }^{6}$, Laszlo Nagy ${ }^{6,7,8}$, Jozef Dulak ${ }^{1}$ and Alicja Jozkowicz ${ }^{1^{*}}$

\begin{abstract}
Background: Peroxisome proliferator-activated receptor-y (PPARY) agonists, which have been used as insulin sensitizers in diabetic patients, may improve functions of endothelial cells (ECs). We investigated the effect of PPARY on angiogenic activities of murine ECs and bone marrow-derived proangiogenic cells (PACs).

Methods: PACs were isolated from bone marrow of 10-12 weeks old, wild type, $\mathrm{db} / \mathrm{db}$ and PPARy heterozygous animals. Cells were cultured on fibronectin and gelatin coated dishes in EGM-2MV medium. For in vitro stimulations, rosiglitazone $(10 \mu \mathrm{mol} / \mathrm{L})$ or GW9662 $(10 \mu \mathrm{mol} / \mathrm{L})$ were added to $80 \%$ confluent cell cultures for 24 hours. Angiogenic potential of PACs and ECS was tested in vitro and in vivo in wound healing assay and hind limb ischemia model.

Results: ECs and PACs isolated from diabetic db/db mice displayed a reduced angiogenic potential in ex vivo and in vitro assays, the effect partially rescued by incubation of cells with rosiglitazone (PPARY activator). Correction of diabetes by administration of rosiglitazone in vivo did not improve angiogenic potential of isolated PACs or ECs. In a hind limb ischemia model we demonstrated that local injection of conditioned media harvested from wild type PACs improved the blood flow restoration in $\mathrm{db} / \mathrm{db}$ mice, confirming the importance of paracrine action of the bone marrow-derived cells.

Transcriptome analysis showed an upregulation of prooxidative and proinflammatory pathways, and downregulation of several proangiogenic genes in db/db PACs. Interestingly, db/db PACs had also a decreased level of PPARy and changed expression of PPARy-regulated genes. Using normoglycemic PPARY ${ }^{+-}$mice we demonstrated that reduced expression of PPARY does not influence neovascularization either in wound healing or in hind limb ischemia models.
\end{abstract}

Conclusions: In summary, activation of PPARY by rosiglitazone improves angiogenic potential of diabetic ECs and PACs, but decreased expression of PPARy in diabetes does not impair angiogenesis.

Keywords: Diabetes, PPARY, Therapeutic angiogenesis, Endothelial progenitor cells

\footnotetext{
* Correspondence: alicja.jozkowicz@uj.edu.pl

'Department of Medical Biotechnology, Krakow, Poland

Full list of author information is available at the end of the article
} 


\section{Introduction}

Peroxisome proliferator-activated receptor gamma (PPAR $\gamma)$ is a ligand-dependent transcription factor of nuclear receptor superfamily, involved in regulation of lipid metabolism, insulin sensitivity, and inflammatory response [1,2]. Synthetic PPARy agonists (thiazolidinediones), such as rosiglitazone (ROSI), pioglitazone, and troglitazone, have been used for many years in patients with type 2 diabetes (T2DM) to improve insulin resistance and ameliorate hyperglycemia [3].

Diabetes, due to hyperglycemia and insulin resistance, is associated with poor outcomes due to endothelial dysfunction and impaired angiogenesis, followed by vascular occlusive events, decreased vascular density in ischemic tissues, and delayed wound healing $[4,5]$. Proper vascular repair and angiogenesis depend both on mature endothelial cells and endothelial progenitors [6,7]. Bone marrowderived endothelial progenitor cells (EPCs) were first characterized in 1997 as a CD34 ${ }^{+}$population mobilized into the peripheral blood in response to ischemia, capable of incorporating into injured vessels and involved in tissue revascularization [8]. In further studies a broad spectrum of protocols for isolation or characterization of EPCs has been used, which makes the comparison of the results difficult. It seems, however, that cells named EPCs are rather a heterogenous population containing mainly monocytes with angiogenic properties [9]. They can produce a range of growth factors including the vascular endothelial growth factor-A (VEGF-A), stromal cellderived factor-1 (SDF-1), or interleukin-8 (IL-8), and this paracrine activity is supposed to be the most important for compensatory vascularization in ischemic tissues [10-12]. Despite lack of standardized definition, the analyzes have consistently indicated that the bone marrowderived proangiogenic cells are altered in type 2 diabetes. Either in animal models or in human patients, diabetes reduces number of EPCs, impairs their mobilization, and decreases their angiogenic potential [13-18].

The deleterious effects of diabetes on mature endothelium and bone marrow-derived proangiogenic cells can be favorably modulated by PPAR $\gamma$ agonists. Hence, treatment with rosiglitazone facilitated reendothelialization in diabetic patients, through decreased ROS generation and improved bioavailability of nitric oxide (NO) in endothelial cells [19]. It also increased the number of circulating EPCs and normalized their migratory activity [20]. Importantly, PPAR $\gamma$ agonists may improve endothelial functions and angiogenic capacities independently of insulin sensitizing in normoglycemic patients [21-23]. They were also shown to upregulate expression of VEGF in rat and human vascular smooth muscle cells $[24,25]$.

Direct proangiogenic activity of PPARY agonists have been described in human umbilical vein endothelial cells (HUVECs), where expression of VEGF receptor-2
(VEGFR-2) and formation of cord-like structures on Matrigel were enhanced in response to troglitazone [26]. However, the effect of PPAR $\gamma$ on angiogenic activities of endothelial cells is still not clear, as inhibition of cordlike structure formation, decreased proliferation, and impaired migration have also been reported in HUVECs treated with PPARY agonists [27,28]. Moreover, while there are numerous papers on vascular effects of PPAR $\gamma$ agonist, much less is known about potential consequences of PPAR $\gamma$ deficiency or inhibition. It has been shown that administration of PPAR $\gamma$ antagonist (T0070907) in pregnant rats led to endothelial dysfunction, reduced expression of VEGF and increased level of plasma soluble VEGF receptor-1 (sVEGFR-1), which acts as a VEGF scavenger [29]. Accordingly, lack of PPAR $\gamma$ impaired vascular proliferation and led to vasculature defects in murine placentas, what was a unique cause of PPAR $\gamma^{-1-}$ lethality [30]. These observations indicate that proper expression of PPAR $\gamma$ may be an important issue in regulation of angiogenesis. Therefore, we examined the effects of PPAR $\gamma$ activation and PPARY inhibition on angiogenic activities of endothelial and bone marrow-derived proangiogenic cells (PACs) in diabetic and normoglycemic conditions.

\section{Materials and methods Reagents}

Endothelial cell basal medium-2 (EBM-2) with a growth factor supplement was obtained from Lonza. MCDB-131 medium, phosphate buffered saline (PBS), Accutase and fetal bovine serum (FBS) were from PAA Laboratories. BS1 lectin was purchased from Vector Laboratories. DiI labeled acetylated low density lipoproteins (DiI-AcLDL) were from Invitrogen and QCM cell migration assay from Chemicon. Mouse VEGF ELISA, mouse SDF-1 ELISA, and growth factor-reduced Matrigel were obtained from R\&D Systems. Fenozol was obtained from A\&A Biotechnology. Anti-mouse proliferating cell nuclear antigen (PCNA) antibody was purchased from Dako. Anti-mouse antibodies against stem cell antigen-1 (Sca-1), chemokine receptor type-4 (CXCR4), CD45, and kinase insert domain receptor (KDR, VEGFR-2) used for immunophenotyping of PACs, antibodies recognizing mouse CD31 used for immunohistochemistry and PharmLyse were obtained from BD Biosciences. All other reagents were purchased from Sigma.

\section{Cell culture}

PACs were cultured as described earlier [12]. In short: total bone marrow cells were flashed from tibias and femurs of mice and centrifuged on Ficoll gradient. Cells from the interphase were washed three times with PBS, seeded on fibronectin $(20 \mu \mathrm{g} / \mathrm{mL})$ and gelatin $(0.25 \%)$ coated dishes in EGM-2MV medium (EBM-2 with growth factor supplement) containing $10 \% \mathrm{FBS}$, and cultured up 
to $80 \%$ confluence for $9-11$ days in standard conditions (humidified atmosphere, $21 \% \mathrm{O}_{2}, 5 \% \mathrm{CO}_{2}$ ). In some experiments the cells were cultured in hypoxia $\left(2 \% \mathrm{O}_{2}, 5 \%\right.$ $\mathrm{CO}_{2}$ for 24 hours). Phenotype of the cultured cells was validated by uptake of DiI-AcLDL $(10 \mu \mathrm{g} / \mathrm{mL})$, binding of FITC-labeled BS1 lectin, expression of progenitor, endothelial or hematopoietic marker mRNAs, and presence of Sca-1, CXCR4, KDR and CD45 proteins.

For in vitro stimulations, rosiglitazone $(10 \mu \mathrm{mol} / \mathrm{L})$ or GW9662 (10 $\mu \mathrm{mol} / \mathrm{L})$ were added to $80 \%$ confluent cell cultures for 24 hours. In case of PPAR $\gamma$ inhibition with GW9662 followed by stimulation with rosiglitazone the inhibitor was added first, 30 minutes ahead.

HUVECs were cultured in MCDB-131 complete medium, supplemented with 10\% FBS endothelial cell growth supplement (ECGS) and hydrocortizone [12].

\section{Animals}

All experiments were approved by the Local Ethical Committee for Animal Research at the Jagiellonian University. Mice were handled according to good animal practice in science, with a food and water access ad libitum. Wild type and $\mathrm{db} / \mathrm{db}$ mice (C57BLKS background) were purchased from Taconic (Denmark), whereas PPAR $\gamma$ wild type and heterozygous animals (C57BL/6 J background) were kindly provided by Dr. Laszlo Nagy (University of Debrecen). In all experiments 10-12 weeks old mice were employed. For in vivo drug delivery mice were treated daily for two weeks by oral gavage either with rosiglitazone (10 $\mathrm{mg} / \mathrm{kg}$ body weight) or placebo (control WT and $\mathrm{db} / \mathrm{db}$ mice).

\section{Migration}

$80 \%$ confluent PACs were detached using Accutase. Next, 10,000 cells were seeded in EBM-2 empty medium on the top of $8-\mu \mathrm{m}$ transwell filters and stimulated with rosiglitazone $(10 \mu \mathrm{mol} / \mathrm{L})$ and/or GW9662 (10 $\mu \mathrm{mol} / \mathrm{L}$, added 30 minutes before rosiglitazone). Lower chamber was filled with EGM-2MV medium supplemented with $10 \%$ FBS. Cells were incubated overnight under standard culture conditions. Then, the migrated cells on the underside of the membrane were fixed in 3\% paraformaldehyde for 10 minutes, washed with PBS and stained with crystal violet solution, according to vendor's protocol. For each sample the number of cells was calculated as mean cell count of 10 randomly-selected microscopic fields using Nikon Eclipse TX-100 microscope.

\section{Tube formation on matrigel}

Growth factor-reduced Matrigel was poured into a 96-well plate $(50 \mu \mathrm{L} /$ well $)$ and incubated at $37^{\circ} \mathrm{C}$ for 15 minutes. Then 20,000 PACs were seeded to each well and stimulated with rosiglitazone $(10 \mu \mathrm{mol} / \mathrm{L})$ and/or GW9662 $(10 \mu \mathrm{mol} /$ $\mathrm{L}$, added 30 minutes before rosiglitazone). Resulting tube- like structures were counted in whole well after the $16 \mathrm{~h}$ incubation period using Nikon Eclipse TX-100 microscope.

\section{Proliferation assay}

PACs were seeded in chamber slides and cultured in standard conditions until reaching a confluence of $70 \%$. Proliferating cells were stained with anti-mouse PCNA antibody and PCNA-positive cells were counted using the fluorescence microscope (Nikon Eclipse TX-100).

\section{Flow cytometry}

PACs number in the peripheral blood and in the bone marrow was measured on the basis of analysis of CD $45^{-} \mathrm{KDR}^{+} \mathrm{Sca}-1^{+}$population. Peripheral blood was harvested from vena cava superior into heparinized syringe, whereas bone marrow was flushed from tibias and femurs. Next, red blood cells were removed with PharmLyse buffer and, after washing, cells were incubated with anti-mouse antibodies (APC-Cy7 CD45, FITC Sca-1 and APC KDR) for 30 minutes at $4^{\circ} \mathrm{C}$ in RPMI 1640 medium containing 2\% FBS. Data were collected from at least 1,000,000 events using a cytofluorometer (LSR II; Becton Dickinson) and analyzed using FACSDiva software (BD Biosciences).

\section{ELISA}

Concentrations of VEGF and SDF-1 proteins in blood plasma and tissue lysates were measured by ELISA tests according to vendor's protocol.

\section{Gene expression analysis}

Total RNA was isolated from PACs and from bone marrow (after lysis of red blood cells) with a modified guanidinium isothiocyanate method. For cDNA synthesis $0.5 \mu \mathrm{g}$ RNA was used. Gene expression was measured by real time PCR (StepOnePlus, Applied Biosystems) according to the protocol: $95^{\circ} \mathrm{C}$ for 5 minutes followed by 40 cycles of melting at $95^{\circ} \mathrm{C}-30 \mathrm{~s}$, annealing at $58-62^{\circ} \mathrm{C}-60 \mathrm{~s}$, elongation at $72^{\circ} \mathrm{C}-45 \mathrm{~s}$. Primer sequences, annealing temperatures, and length of PCR products are listed in Additional file 1: Table S1.

\section{Wound healing}

Wound healing assay was performed as described previously [31]. Two full-thickness circular wounds (4 $\mathrm{mm}$ in diameter) on each animal were created using disposable biopsy punch. Each wound was photographed every day and analyzed using ImageJ software.

\section{Hind limb ischemia}

Left femoral artery ligation was performed to induce limb ischemia in WT, PPAR $\gamma$ deficient and $\mathrm{db} / \mathrm{db}$ mice. The superficial blood flow of the ischemic and contralateral foot was analyzed by a laser Doppler flowmeter 
(Periflux). Ratio between blood flow in the ischemic foot and in contralateral foot was calculated and used as an index of blood flow recovery.

For cell therapy, PACs were isolated from WT mice and cultured up to confluence in standard conditions. Then the growth medium was changed to EBM-2 containing $0.5 \%$ FBS, which was harvested after a $24 \mathrm{~h}$ incubation period to obtain PAC-conditioned medium. Conditioned media were frozen for further use. Diabetic mice $(\mathrm{db} / \mathrm{db})$ were subjected to femoral artery ligation and next day the conditioned media, control media (EBM-2 with $0.5 \%$ FBS) or PACs $(250,000$ cells in control medium) in a total volume of $50 \mu \mathrm{L}$ were injected intramuscularly into 3 sites of ischemic gastrocnemius muscle. Blood flow measurements were performed weekly till $28^{\text {th }}$ day after injections. At the end of experiment gastrocnemius muscles were frozen for immunohistochemical and histochemical analyzes.

\section{Immunohistochemical staining}

Vascularization of gastrocnemius muscles was assessed by CD31 staining of endothelial cells. For this purpose, frozen sections of muscle $(6 \mu \mathrm{m})$ were dried for $1 \mathrm{~h}$ in room temperature and then fixed for 10 minutes in acetone $\left(4^{\circ} \mathrm{C}\right)$. Sections were blocked in $10 \%$ goat serum, $0.05 \%$ Tween-20, $0.1 \%$ TritonX-100 for $1 \mathrm{~h}$ in room temperature, and then incubated with anti-mouse CD31 antibodies for $1.5 \mathrm{~h}$. After washing, sections were incubated with rhodamine-labeled secondary antibodies for 30 minutes in room temperature, washed and mounted in fluorescent mounting medium. The number of capillaries per muscle fiber were counted from 10 random fields for each specimen using Nikon Eclipse TX-100 microscope.

\section{Statistical analysis}

Results are expressed as mean \pm SEM. In vitro experiments were carried out 3-10 times. In vivo experiments were done with 5-9 mice per group. Two tailed Student's $t$ test was used for comparison of two groups, while oneway ANOVA with Bonferroni posttest way applied for comparison of multiple groups.

Full length description of methods is available in the supplemental file.

\section{Results}

\section{Characterization of bone marrow-derived PACs}

Bone marrow-derived proangiogenic cells isolated from healthy C57BL6/J (wild type, WT) mice and cultured for 9-11 days under conditions promoting the endothelial differentiation, generated a heterogeneous population, with $80-90 \%$ of cells incorporating acLDL and binding BS1 lectin, capable of forming the capillary-like structures after seeding on Matrigel
(Additional file 2: Figure S1A-D), which confirmed our earlier observation [12]. Such population was 450- to 650-fold enriched in $\mathrm{CD} 45^{-} \mathrm{KDR}^{+} \mathrm{Sca}-1^{+}$cells comparing to freshly isolated bone marrow, although their content, even after such enrichment, did not exceed 0.5\%. PACs derived from $\mathrm{db} / \mathrm{db}$ diabetic mice displayed similar morphology or acLDL and BS1 staining and similar level of enrichment in $\mathrm{CD}_{4} 5^{-} \mathrm{KDR}^{+} \mathrm{Sca}-{ }^{+}$cells (data not shown).

Transcriptome analysis revealed that expression of genes typical for progenitor cells (e.g. Sca-1, c-kit, CD34), endothelial cells (e.g. $\mathrm{KC}$, vascular cell adhesion molecule1 (VCAM-1), endoglin, von Willebrand factor (vWF), and hematopoietic cells (e.g. CD11b, CD14) can be detected in the heterogeneous PAC populations at the levels similar in WT and db/db cells (data not shown). FACS immunophenotyping showed that vast majority of PACs expressed CD45, a pan-hematopoietic marker, and proportion of such cells was slightly higher in the $\mathrm{db} / \mathrm{db}$ than in WT cultures $(85 \pm 1 \%$ vs. $77 \pm 1 \%)$. On the other hand, frequency of KDR-positive cells, these expressing typical endothelial marker, was lower in population isolated from $\mathrm{db} / \mathrm{db}$ mice $(5 \pm 1 \% v s .10 \pm 2 \%$. More than $60 \%$ of both WT and $\mathrm{db} / \mathrm{db}$ cells were positive for CXCR4 and Sca-1 markers, preferentially expressed on progenitor cells (Additional file 2: Figure S1E).

\section{Angiogenic potential of PACs}

In a set of in vitro experiments we compared angiogenic potential of wild type and $\mathrm{db} / \mathrm{db}$ PACs. Spontaneous proliferation, measured using immunohistochemical detection of PCNA, was similar in cells isolated from healthy and diabetic animals (Figure 1A). All other activities measured, namely migration (Figure 1B), sprouting of capillaries from PACs spheroids embedded in collagen (Figure 1C), and formation of cord-like structures on Matrigel (Figure 1D) were attenuated in $\mathrm{db} / \mathrm{db}$ cells, indicating their impaired angiogenic potential. Similarly, angiogenic activity of mature endothelial cells derived from aorta of $\mathrm{db} / \mathrm{db}$ mice tended to be weaker, as illustrated by the results of semiquantitative ring assay (Figure 1E).

Since angiogenesis can be stimulated by bone marrowderived cells in a paracrine way, we also evaluated the effect of conditioned media collected from the cultured PACs on HUVEC cells seeded on Matrigel. As shown in Figure 1F, PACs isolated from diabetic mice displayed a weaker paracrine activity - they induced formation of sparser capillary network by HUVEC endothelial cells (Figure 1F).

\section{Effect of rosiglitazone on angiogenic potential of PACs}

There are discrepancies between papers describing either proangiogenic [5,20-22,32], antiangiogenic [27,28,33-35] 

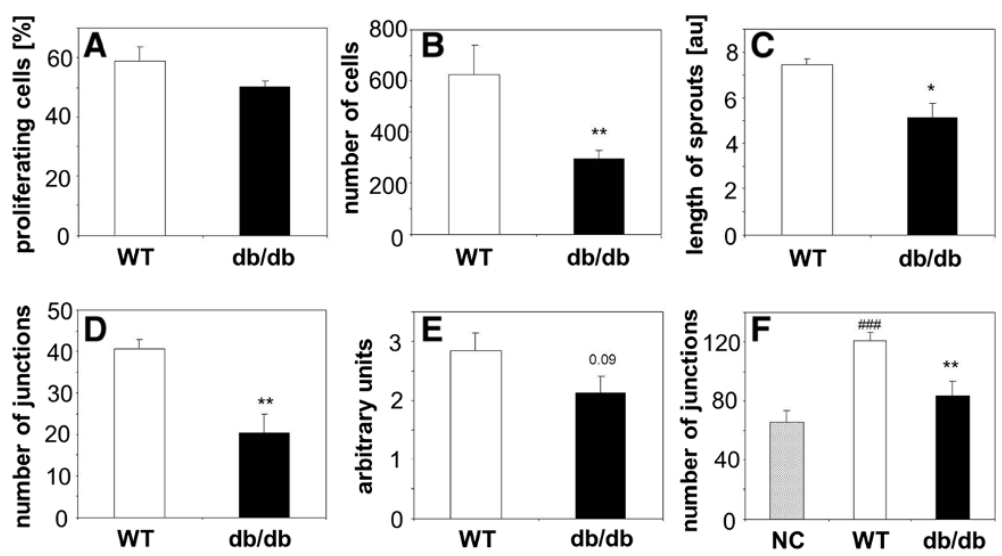

Figure 1 Angiogenic potential of PACs and endothelial cells from wild type (WT) and diabetic (db/db) mice. A: Proliferation of PACs. Immunohistochemical detection of PCNA-positive cells. B: Migration of PACs in modified Boyden chambers. C: Formation of sprouts from PACs spheroids embedded in collagen gel, shown as a total length of sprouts per one spheroid. D: Formation of cords by PACs seeded on Matrigel shown as a number of cord junctions per microscopic field. E: Formation of capillaries by endothelial cells from aortic rings isolated from WT or $\mathrm{db} / \mathrm{db}$ mice and plated on Matrigel. F: Formation of cords by HUVECs seeded on Matrigel and stimulated with empty medium (NC, negative control) or conditioned media from WT PACs and db/db PACs, shown as a number of cord junctions per microscopic field. Each bar represents mean + SEM. N = 4-5 (1A-E), N=8-9 (1F), ${ }^{*} p<0.05,{ }^{* *} p<0.01$ versus $W T, \# \# p 0.001$ versus NC.

or biphasic [36] effects of PPAR $\gamma$ agonists. Therefore we checked whether impaired angiogenic potential of PACs isolated from $\mathrm{db} / \mathrm{db}$ mice can be corrected by rosiglitazone. Cells were exposed to rosiglitazone $(10 \mu \mathrm{mol} / \mathrm{L})$ for $24 \mathrm{~h}$. This resulted in a significant upregulation of PPAR activity, which we tested using PPRE-luciferase reporter plasmid (data not shown). To confirm PPAR $\gamma$ specificity, some cells were preincubated with GW9662 (10 $\mu \mathrm{mol} / \mathrm{L}, 30$ minutes), PPAR $\gamma$ antagonist.

Modulation of PPAR $\gamma$ activity did not influence significantly the proliferation of PACs (Figure 2A), although there was a tendency toward inhibition of proliferation in cells treated with GW9662 ( $p=0.08$ and $p=0.07$ in WT and $\mathrm{db} / \mathrm{db}$ cells). In contrast, migration (Figure $2 \mathrm{~B}$ ) and formation of cord-like structures on Matrigel (Figure 2C), two activities which were impaired in PACs isolated from $\mathrm{db} / \mathrm{db}$ mice, were rescued in $\mathrm{db} / \mathrm{db}$ cells incubated with rosiglitazone. This effect was at least partially blocked by GW9662, confirming the PPAR $\gamma$-dependency. Interestingly, rosiglitazone did not improve migration or formation of cord-like structures in wild type PACs (Figure 2B, C). Also, rosiglitazone showed a tendency to augment angiogenic activity of mature endothelial cells $(p=0.08)$ in aortal rings derived from $\mathrm{db} / \mathrm{db}$ mice, without effects on the cells isolated from wild type animals (Figure 2D,E).

Next, we tested effects of rosiglitazone $(10 \mu \mathrm{mol} / \mathrm{L}, 24 \mathrm{~h})$ on expression of genes involved in angiogenesis, focusing on two major agents, VEGF and SDF-1. Expression of VEGF, similar in the cultured wild type and $\mathrm{db} / \mathrm{db}$ PACs, was upregulated in response to rosiglitazone. This upregulation was slightly, but significantly weaker in cells isolated from diabetic mice (Figure 3A). However, we did not see changes on a protein level (data not shown). Expression of
KDR (Flk-1, VEGFR-2), the major receptor mediating the proangiogenic VEGF action, was higher in $\mathrm{db} / \mathrm{db}$ cells, and not modified by rosiglitazone (Figure 3B), while Flt-1 (VEGFR-1) level was affected neither by diabetes nor by rosiglitazone (Figure 3C). Like in the case of VEGF, expression of SDF-1 was similar in control wild type and $\mathrm{db} / \mathrm{db}$ PACs. Treatment with rosiglitazone showed a tendency toward decrease in SDF-1 levels (Figure 3D), but this effect did not reach statistical significance $(p=0.06$ in control PACs and $p=0.12 \mathrm{in} \mathrm{db} / \mathrm{db}$ PACs). The same trend was observed for protein level (data not shown). Its major receptor, CXCR4 was, however, downregulated in $\mathrm{db} / \mathrm{db}$ cells, the effect not modified by rosiglitazone (Figure 3E). Expression of CXCR-7 receptor was the same in all experimental groups (Figure 3F). Additionally, we found that both in wild type and $\mathrm{db} / \mathrm{db}$ PACs rosiglitazone significantly increased production of $\mathrm{KC}$, a potent proangiogenic chemokine (Figure 3G). Cells cultured with rosiglitazone showed also increased expression of two genes which may promote differentiation of proangiogenic precursors, namely angiotensinogen (Figure $3 \mathrm{H}$ ) and proteolycan-4 (Figure 3I).

\section{Effect of therapy with rosiglitazone on PACs and endothelial cells in diabetic mice}

Subsequently, we tested whether therapy with rosiglitazone would correct angiogenic functions of PACs and mature endothelial cells in diabetic mice. As expected, daily oral administration of rosiglitazone $(10 \mathrm{mg} / \mathrm{kg}$ for 14 days) caused the increase in body mass by about $20 \%$ of initial values (Additional file 3: Figure S2A). Concomitantly, all measured biochemical parameters, like glucose, cholesterol, and triglycerides concentrations, together with 

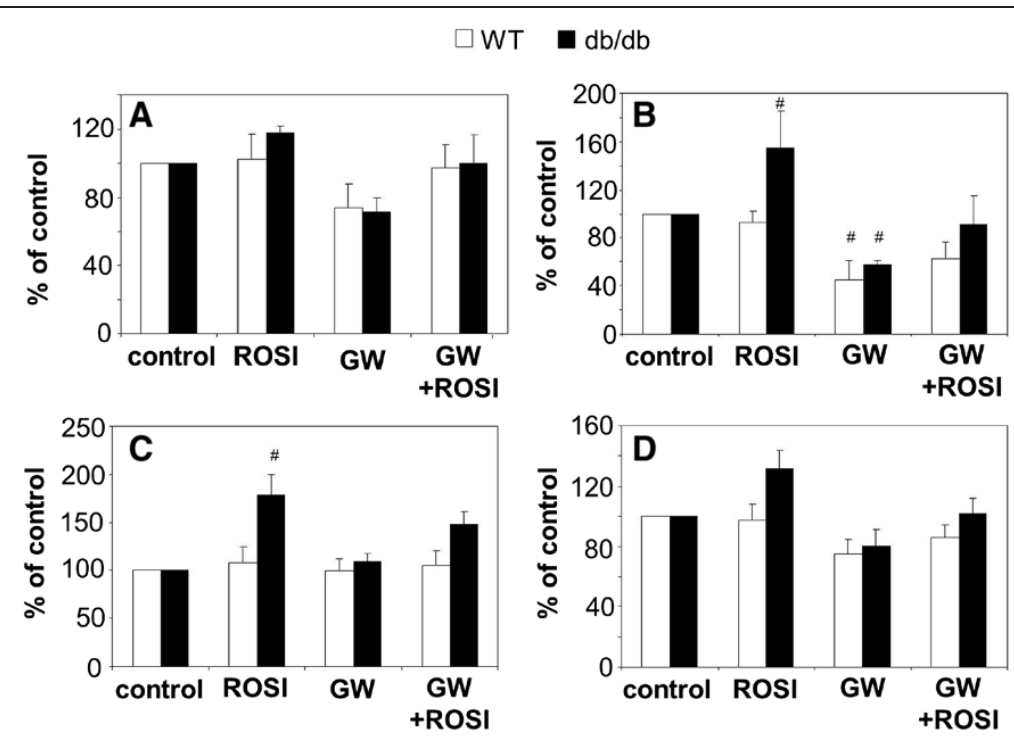

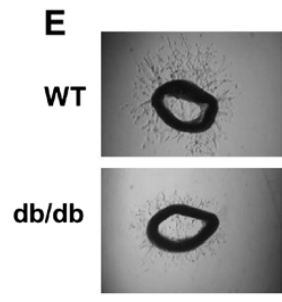

control

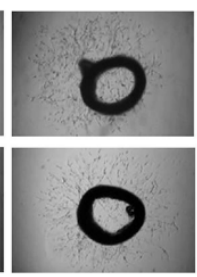

ROSI

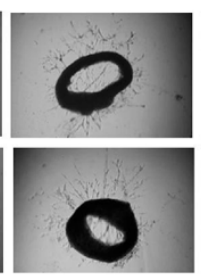

GW

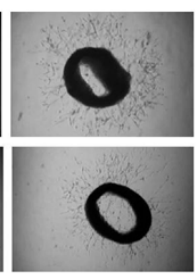

GW+ROSI

Figure 2 Effect of PPAR y agonist rosiglitazone (ROSI, $10 \mu \mathrm{mol} / \mathrm{L}, 24 \mathrm{~h}$ ) and PPAR $y$ antagonist GW9662 (GW, $10 \mu \mathrm{mol} / \mathrm{L}, 24 \mathrm{~h}$ ) on angiogenic potential of PACs and endothelial cells from wild type (WT) or diabetic (db/db) mice. A: Proliferation of PACs.

Immunohistochemical detection of PCNA-positive cells. B: Migration of PACs in modified Boyden chambers. C: Formation of cords by PACs seeded on Matrigel, shown as a number of cord junctions per microscopic field. D: Formation of capillaries by endothelial cells from aortic rings isolated from WT or db/db mice and embedded in Matrigel. E: representative pictures showing aortic rings. Each bar represents mean + SEM, expressed as percentage of values for untreated control. $\mathrm{N}=4-5, " \# p 0.05$ versus control.

percentage of glycated hemoglobin (HbA1c), were significantly elevated in diabetic animals and reduced after treatment with rosiglitazone (Additional file 3: Figure S2B-E). Hematological parameters of peripheral blood were not changed, apart from a total number of leukocytes, which was lower in $\mathrm{db} / \mathrm{db}$ mice, regardless of rosiglitazone treatment (Additional file 1: Table S2).

Flow cytometric analysis showed that endothelial progenitors (EPCs), defined as CD $45^{-} \mathrm{KDR}^{+} \mathrm{Sca}-1^{+}$cells, were significantly less frequent in the bone marrow of diabetic mice. Treatment with rosiglitazone resulted in a partial restoration of bone marrow EPCs pool (Figure 4A, $p=$ 0.06), which was complete after prolongation of treatment time to 28 days (data not shown). Decreased frequency of $\mathrm{CD} 45^{-} \mathrm{KDR}^{+} \mathrm{Sca}-1^{+}$cells was found also in the peripheral blood of diabetic animals, although this tendency did not reach statistical significance (Figure $4 \mathrm{~B}$ ). The number of circulating EPCs was, however, strongly reduced in $\mathrm{db} / \mathrm{db}$ mice and not affected by rosiglitazone (Figure 4A-C).

In parallel with changes in the bone marrow EPC pool, we observed a similar pattern (decrease in diabetic mice partially restored by rosiglitazone) in expression of VEGF, both at the mRNA and protein levels (Figure 4D, E). In contrast, concentration of VEGF in the blood was the same in all experimental groups (Figure 4F). On the other hand, expression of SDF-1 mRNA was the same in the bone marrow of wild type and $\mathrm{db} / \mathrm{db}$ mice, but decreased in response to rosiglitazone (Figure 4G). Concentration of SDF-1 protein did not reflect, however, the level of mRNA expression and was increased in rosiglitazone treated mice (Figure $4 \mathrm{H}$ ). This increase was not observed in the blood, where SDF-1 concentrations were lower in diabetic animals (Figure 4I). Noteworthy, expression of PPAR $\gamma$ in the bone marrow of diabetic $\mathrm{db} /$ $\mathrm{db}$ mice was reduced by approximately $50 \%$ and was not changed in response to rosiglitazone (Figure 4J).

We compared also the angiogenic potential of cultured PACs isolated from diabetic animals treated for two weeks with rosiglitazone with that from the untreated diabetic mice or wild type animals. Analysis of PAC migration and sprouting of capillaries from PAC spheroids showed the impaired activity of cells derived from diabetic animals, 

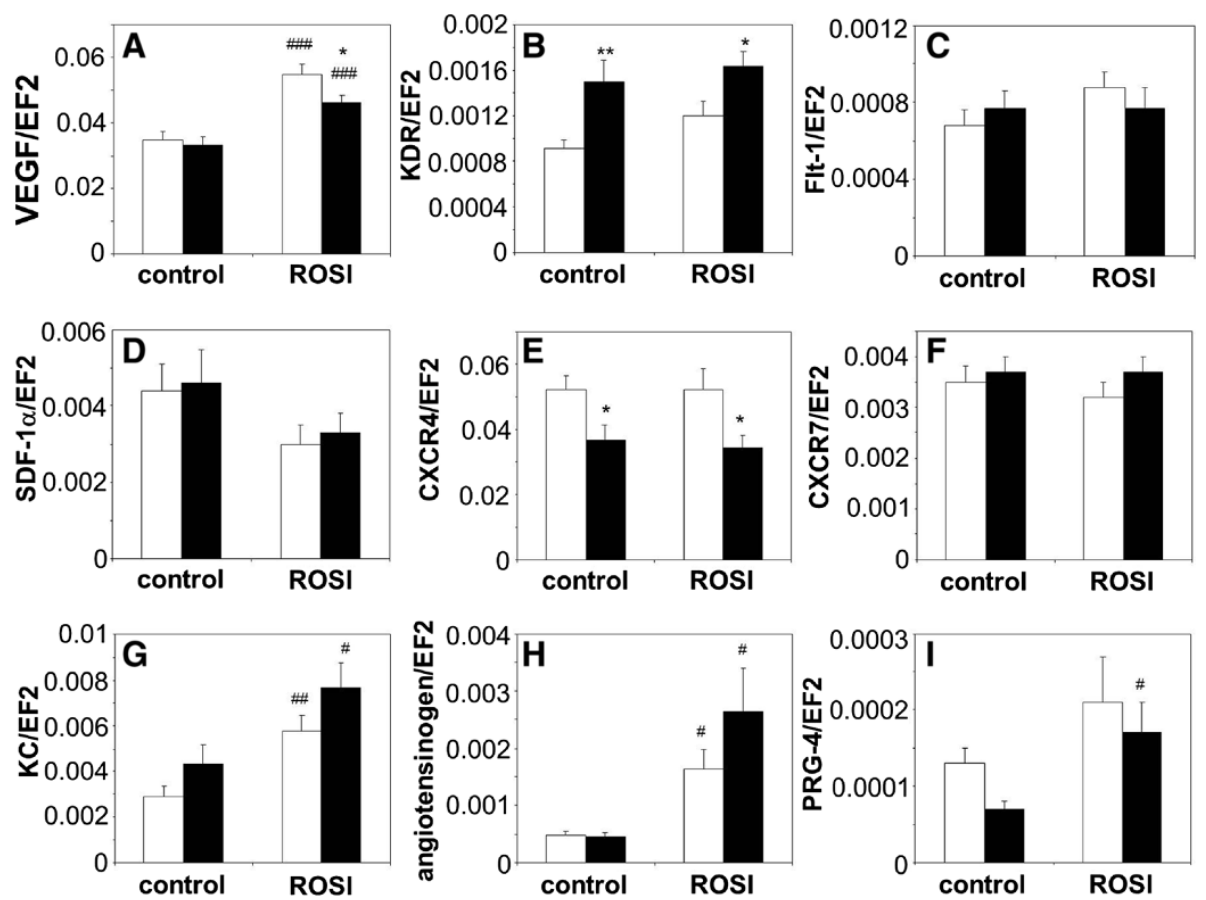

Figure 3 Effect of PPARy agonist rosiglitazone (ROSI, $10 \mu \mathrm{mol} / \mathrm{L}, 24 \mathrm{~h}$ ) on expression of proangiogenic genes in PACs from wild type (WT) and diabetic (db/db) mice. PACs cultured without ROSI are used as a control. A: VEGF. B: KDR. C: Flt-1. D: SDF-1. E: CXCR4. F: CXCR7. G: KC. H: Angiotensinogen. I: PRG-4. Quantitative RT-PCR. EF2 serves as an internal control. Each bar represents mean $+\mathrm{SEM} . \mathrm{N}=8-10,{ }^{*} p<0.05$, ${ }^{* *} p<0.01$ versus WT, ${ }^{\#} p<0.05,{ }^{\# \#} p<0.01,{ }^{\# \# \#} p<0.001$ versus control.

regardless of the treatment with rosiglitazone and despite the correction of metabolic status (data not shown). Similarly, paracrine potential of PACs and angiogenic activity of mature endothelial cells isolated from aorta were not rescued in diabetic mice treated with rosiglitazone (data not shown).

\section{Conditioned media from PACs improve blood flow restoration in diabetic mice}

We checked whether PACs isolated from nondiabetic, wild type individuals may improve the blood flow restoration in ischemic muscles after hind limb ischemia in diabetic mice. To assess the importance of paracrine activity of PACs we compared effect of a) locally transplanted PACs and b) locally injected conditioned media harvested from PACs. Femoral artery ligation in $\mathrm{db} / \mathrm{db}$ mice was followed either by injection of non-conditioned, empty medium ("control"), PACs isolated from syngeneic wild type mice and cultured in vitro ("cells"), or conditioned media harvested from such cells ("media"). Measurements of perfusion done immediately after surgery (day 0) and on days $7^{\text {th }}, 14^{\text {th }}, 21^{\text {st }}$, and $28^{\text {th }}$ showed that blood flow recovery in control diabetic mice was not effective, as on day $28^{\text {th }}$ it still did not reach a $50 \%$ of perfusion measured before surgery. However, this process was enhanced in animals injected with conditioned media on day $28^{\text {th }}$, what confirms the importance of paracrine influence of bone marrow derived cells. Transplantation of PACs was less effective, or could even slow down the recovery from ischemia at early time points (Figure 5A). There was also a tendency toward a higher proportion of regenerating fibers in the group injected with conditioned media in comparison to control group (Figure 5B), not significant in the group subjected to PAC transplantation $(p>0.3)$. Immunohistochemical analyzes performed on day $28^{\text {th }}$ showed no differences in density of CD31-positive capillaries between experimental groups (Figure 5C). However, there was a higher number of $\alpha$ SMA-positive arterioles in animals treated with conditioned media and a similar tendency in the group after PAC transplantation (Figure 5D). No statistically significant changes in frequency or number of $\mathrm{CD} 45^{-} \mathrm{KDR}^{+} \mathrm{Sca}-1^{+}$cells were found at this time point either in bone marrow or in peripheral blood (data not shown).

\section{Gene expression profiles of PACs}

To better understand the effect of diabetes on proangiogenic potential of the bone marrow-derived cells we compared a transcriptome of PACs isolated from the wild type and $\mathrm{db} / \mathrm{db}$ mice. Additionally, for cells of both 

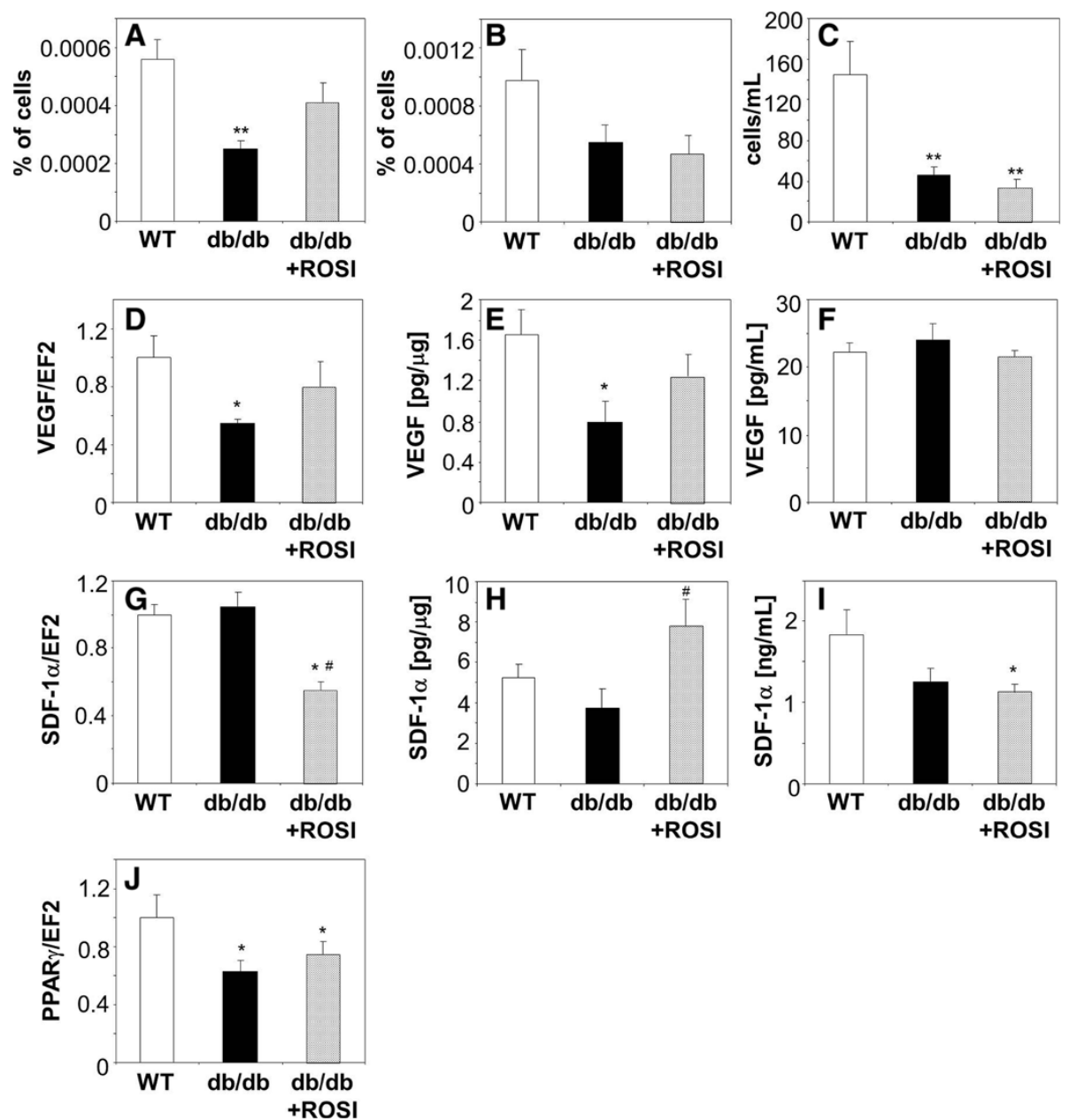

Figure 4 Effect of oral daily administration of PPARY agonist rosiglitazone (ROSI, $10 \mathrm{mg} / \mathrm{kg}$ of body weight, 14 days) on endothelial progenitor cells and expression of proangiogenic genes in diabetic (db/db) mice. Control db/db and wild type (WT) mice were treated with vehicle. A: Percentage of $\mathrm{CD}_{4} 5^{-} \mathrm{KDR}^{+} \mathrm{Sca}-1^{+}$cells in bone marrow. B: Percentage of $\mathrm{CD} 45^{-} \mathrm{KDR}^{+} \mathrm{Sca}-1^{+}$cells in peripheral blood. C: Number of $\mathrm{CD}_{4}{ }^{-} \mathrm{KDR}^{+} \mathrm{SCa}-1^{+}$cells in peripheral blood. Multicolor FACS phenotyping. D: Expression of VEGF mRNA in bone marrow. Quantitative RT-PCR. EF2 serves as an internal control. E: Concentration of VEGF protein in bone marrow. F: Concentration of VEGF protein in peripheral blood. ELISA. G: Expression of SDF-1 mRNA in bone marrow. Quantitative RT-PCR. EF2 serves as an internal control. H: Concentration of SDF-1 protein in bone marrow. I: Concentration of SDF-1 protein in peripheral blood. ELISA. J: Expression of PPARY mRNA in bone marrow. Quantitative RT-PCR. EF2 serves as an internal control. Each bar represents mean + SEM. N =8-10 (4A-C, F, I), N =4-6 (4D, E, G, H, J), ${ }^{*} p<0.05,{ }^{* * *} p<0.01,{ }^{* * * *} p<0.001$ versus WT, ${ }^{\#} p<0.05$ versus $\mathrm{db} / \mathrm{db}$.

genotypes cultured in vitro, we checked the effect of hypoxia, the most important proangiogenic stimulus. Results are summarized in Table 1. Generally, the influence of hypoxia $\left(2 \% \mathrm{O}_{2}\right.$ for the final $24 \mathrm{~h}$ incubation period) on gene expression was similar in the wild type and $\mathrm{db} / \mathrm{db}$ cells, mainly leading to upregulation of genes involved in energetic metabolism, especially in glycolysis.

Comparison of wild type and $\mathrm{db} / \mathrm{db}$ PACs cultured in normoxia revealed that $\sim 700$ transcripts were differentially expressed $(p<0.05)$, including 54 transcripts with more than two-fold difference $(p<0.01)$. Analysis of molecular pathways using GeneGO platform indicated that $\mathrm{db} / \mathrm{db}$ PACs displayed higher expression levels of pro-oxidative genes, such as NADPH-4 oxidase (Nox4), p22phox subunit, or protein kinase $\mathrm{C}-\delta$ (PKC $\delta$ ). It was accompanied by lower levels of cytoprotective genes, such as glutathione S-transferases (GST-1 and GST-3) or glutathione peroxidase-4 (GPX-4) (Table 1). PACs isolated from diabetic mice had also increased expression of proinflammatory genes, e.g. tumor necrosis factor receptor-1 (TNFR-1), granulocyte-colony stimulating factor-3 receptor (G-CSF-3R), CXCL16 chemokine, or P-selectin ligand (Table 1). Similarly, genes associated with remodeling of extracellular matrix, such as MMP-2, MMP-9, MMP-14 and MMP-23 matrix metalloproteinases were upregulated in $\mathrm{db} / \mathrm{db}$ cells (Table 1 ). Diabetic PACs had also higher expression of integrin- $\alpha 1,-\beta 2$ and $-\beta 4$ mRNAs, with concomitant lower expression of genes responsible for 

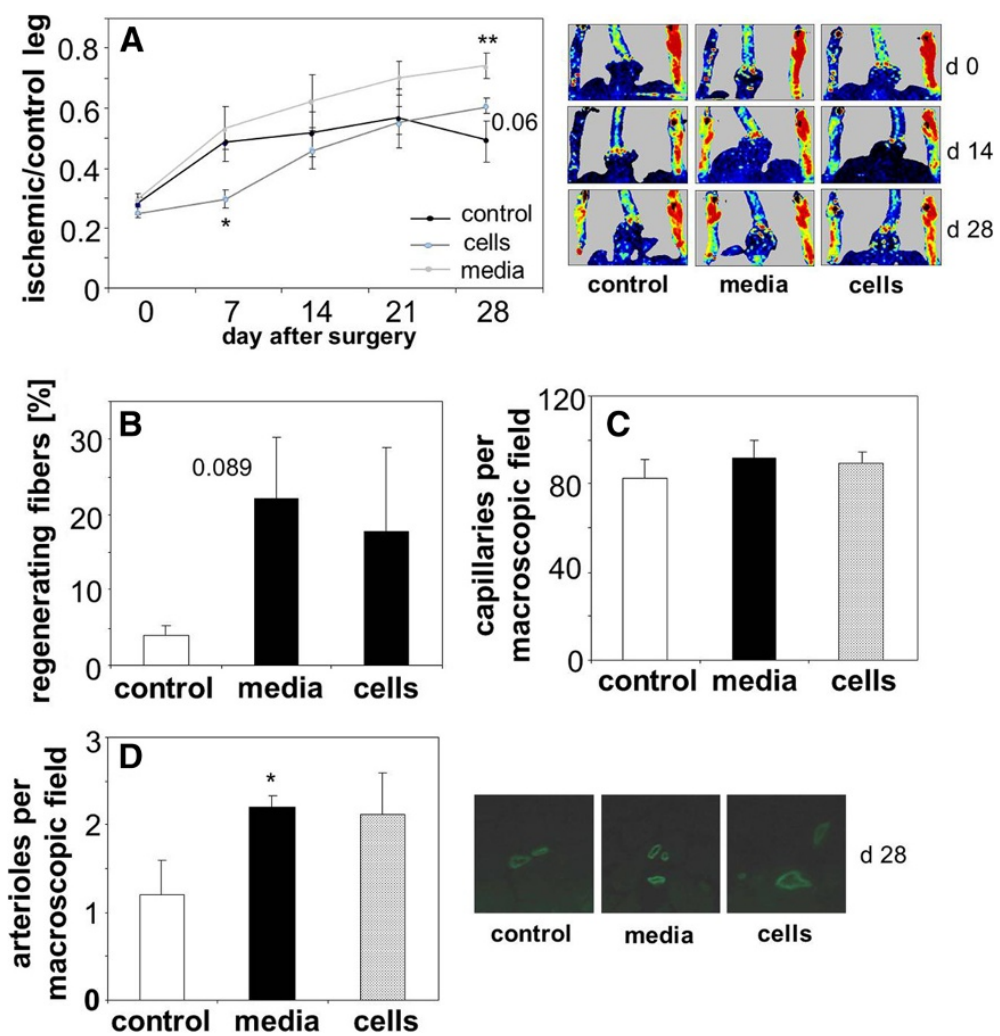

Figure 5 Restoration of blood flow in ischemic muscles in diabetic $(\mathrm{db} / \mathrm{db})$ mice subjected to the hind limb ischemia. Ischemic gastrocnemius was injected either with empty media (control, EBM-2 with 0.5\% FBS), conditioned media (media, EBM-2 with $0.5 \%$ FBS harvested from cultured wild type PACs ), or PACs (cells, $2.5 \times 10^{5}$ in control medium) $24 \mathrm{~h}$ after surgery (injections into 3 sites, total volume of $50 \mu \mathrm{L}$ ). A: Blood flow expressed as a ratio between ischemic and control leg. Numerical data and representative pictures. Laser-Doppler flowmetry. B: Percentage of regenerating fibers in gastrocnemius muscle, 28 days after surgery. Hematoxylin-eosin staining. C: Number of capillaries in gastrocnemius muscle, 28 days after surgery. Immunohistochemical staining for CD31. D: Number of arterioles in gastrocnemius muscle, 28 days after surgery. Immunohistochemical staining for aSMA. Numerical data and representative pictures. $N=4-6,{ }^{*} p<0.05,{ }^{* *} p<0.01$ versus control.

filopodia formation, like efexin (NGEF) or T-complex protein-1 subunit- $\beta$ (CCT2) (Table 1 ), what might be associated with the impaired migration capacity of $\mathrm{db} / \mathrm{db}$ cells. Importantly, expressions of proangiogenic genes, such as fibroblast growth factor-7 (FGF-7), VEGF-C, VEGF-D, or angiogenin, were decreased in PACs isolated from diabetic animals (Table 1).

\section{Expression of PPARy in PACs}

Transcriptome analysis showed that PACs isolated from $\mathrm{db} / \mathrm{db}$ mice had reduced expression of PPAR (Figure 6A). This decrease seems to have a functional effect, as suggested by changes in expression of PPARy targeted genes (Figure 6). We found 8 genes known to be directly regulated by PPAR $\gamma$ [37], which were differently expressed in PACs from wild type and $\mathrm{db} / \mathrm{db}$ mice. Interestingly, expressions of genes positively regulated by PPARy [38-42], namely forkhead box-A1 (FoxA) (Figure 6B), caveolin1 (Figure 6C), 11ß-hydroxysteroid dehydrogenase type 1 (HSD11ß1) (Figure 6D), stearoyl-CoA desaturase-1 (SCD-1) (Figure 6E), and perilipin (Figure 6F) were decreased in $\mathrm{db} / \mathrm{db}$ PACs. In contrast, expression of genes negatively regulated by PPARY $[43,44]$, namely collagen-1 $\alpha 2$ (Figure 6G), pregnancy associated plasma protein-A (PAPP-A) (Figure 6H), and Nox4 (Figure 6I) were increased in $\mathrm{db} / \mathrm{db}$ PACs.

\section{PPAR $y$ heterozygosity in normoglycemic mice does not impair PAC functions}

Proper level of PPAR $\gamma$ is necessary for development of placenta vasculature $[30,45]$, pointing to role of PPARY in angiogenesis. In diabetic $\mathrm{db} / \mathrm{db}$ mice impaired angiogenesis and decrease in number of PACs in bone marrow or peripheral blood is accompanied by the reduced expression of PPARy both in PACs (Figure 6A) and in bone marrow (Figure 4J). Therefore one can hypothesize that downregulation of PPARy expression may be a primary cause of the impairment in PAC or endothelial cell angiogenic potential.

To verify this supposition, in the last set of experiments we investigated angiogenesis in normoglycemic mice carrying one dysfunctional allele of PPAR $\left(\mathrm{PPAR}^{+/-}\right)$. Such animals had a decreased PPAR $\gamma$ mRNA expression both 
Table 1 Analysis of transcriptome of PACs isolated from bone marrow of wild type (WT) or diabetic (db/db) mice and cultured in vitro for 9 days

\begin{tabular}{|c|c|c|c|c|}
\hline Gene & Normoxia & & Hypoxia & \\
\hline Oxidative stress and cytoprotection & WT & $\mathrm{db} / \mathrm{db}$ & WT & $\mathrm{db} / \mathrm{db}$ \\
\hline Nox4 (NOX4) & $148 \pm 20.3$ & $245 \pm 15.2^{*}$ & $153 \pm 25.0$ & $302 \pm 123.8^{\#} 0.082$ \\
\hline Cyba (p22phox) & $29331 \pm 1383.1$ & $35829 \pm 1277.4^{* *}$ & $28248 \pm 2195.8$ & $34380 \pm 5610.4$ \\
\hline Prkcd (PKC $\delta)$ & $3134 \pm 75.8$ & $3698 \pm 286.6^{*}$ & $3667 \pm 518.5$ & $3965 \pm 413.3$ \\
\hline Chst1 (GST-1) & $6979 \pm 411.2$ & $4412 \pm 341.3^{* *}$ & $8339 \pm 562.9$ & $5774 \pm 374.8^{* \#}$ \\
\hline Mgst3 (GST III) & $3388 \pm 453.1$ & $1741 \pm 100.7^{*}$ & $4076 \pm 590.9$ & $2563 \pm 342.6^{*} 0.070 ;{ }^{\#} 0.091$ \\
\hline Gpx4 (GPX4) & $7819 \pm 354$ & $6920 \pm 423.3^{*}$ & $8394 \pm 76.9^{\#}$ & $7599 \pm 614.9^{*} 0.076 ;{ }^{\#} 0.099$ \\
\hline Inflammation & WT & $\mathrm{db} / \mathrm{db}$ & WT & $\mathrm{db} / \mathrm{db}$ \\
\hline Tnfrsf1a (TNFR-1) & $1259 \pm 68.7$ & $1447 \pm 124.7^{*} 0.051$ & $1103 \pm 298.5$ & $1147 \pm 82.5^{\#}$ \\
\hline Csf3r (G-CSF3R) & $188 \pm 6.7$ & $214.9 \pm 9.5^{*}$ & $209 \pm 7.9$ & $237 \pm 36.1$ \\
\hline Cxcl16 (CXCL16) & $2328 \pm 215.3$ & $3194 \pm 403.5^{*}$ & $2464 \pm 319.2$ & $2972 \pm 535.2$ \\
\hline Selplg (P-selectin ligand) & $1930 \pm 219.1$ & $2758 \pm 324.4^{*}$ & $2737 \pm 822.8$ & $3214 \pm 311.0^{\#} 0.077$ \\
\hline Extracellular matrix remodeling & WT & $\mathrm{db} / \mathrm{db}$ & WT & $\mathrm{db} / \mathrm{db}$ \\
\hline Mmp2 (MMP-2) & $2825 \pm 395.2$ & $6498 \pm 1373.3^{*}$ & $2567 \pm 900.6$ & $6454 \pm 905.8^{* *}$ \\
\hline Mmp9 (MMP-9) & $1906 \pm 1005.0$ & $7554 \pm 4171.7^{*} 0.069$ & $1713 \pm 637.0$ & $9625 \pm 955.3^{* * *}$ \\
\hline Mmp14 (MMP-14) & $5081 \pm 513.8$ & $5965 \pm 461.9^{*}$ & $5499 \pm 518.5$ & $5758 \pm 519.5$ \\
\hline Mmp23 (MMP-23) & $1625 \pm 273.8$ & $2127 \pm 267.9^{*}$ & $2396 \pm 521.2^{\#} 0.054$ & $2956 \pm 338.2^{\#}$ \\
\hline Migration and proliferation & WT & $\mathrm{db} / \mathrm{db}$ & WT & $\mathrm{db} / \mathrm{db}$ \\
\hline Itgam (integrin-a1) & $983 \pm 254.4$ & $1397 \pm 30.8^{*} 0.052$ & $1499 \pm 313.8^{\#} 0.096$ & $1397 \pm 498.6^{*}$ \\
\hline Itgb2 (integrin- $\beta 2$ ) & $354 \pm 37.4$ & $438 \pm 30.9^{*}$ & $472 \pm 76.2^{\#}$ & $587 \pm 90.8^{*} 0.085^{\#}$ \\
\hline Itgb4 (integrin- $\beta 4$ ) & $105 \pm 11.2$ & $141 \pm 4.28^{*}$ & $178 \pm 66.0^{\#} 0.096$ & $187 \pm 26.7^{\#}$ \\
\hline Ngef (NGEF) & $163 \pm 2.9$ & $104 \pm 8.2^{* *}$ & $246 \pm 36.2^{\#}$ & $140 \pm 5.7^{\# \# \#}$ \\
\hline Cct2 (CCT2) & $166 \pm 4.0$ & $139 \pm 4.9^{* *}$ & $136 \pm 11.6^{\#}$ & $145 \pm 16.6$ \\
\hline Msx1 (MSX-1) & $184 \pm 18.5$ & $132 \pm 13.7^{* *}$ & $159 \pm 17.8^{\#} 0.081$ & $127 \pm 1.24^{*}$ \\
\hline Cdkl2 (CDKL2) & $233 \pm 17.3$ & $177 \pm 7.4^{* *}$ & $205 \pm 19.7^{\#} 0.066$ & $193 \pm 15.9$ \\
\hline Areg (AREG) & $322 \pm 69.7$ & $118 \pm 14.5^{*}$ & $290 \pm 126.6$ & $155 \pm 39.4^{*} 0.099$ \\
\hline Mdk (midkin) & $236 \pm 6.9$ & $313 \pm 21.6^{* *}$ & $184 \pm 3.1^{\# \# \#}$ & $300 \pm 17.9^{* *}$ \\
\hline Nos3 (NOS3) & $122 \pm 3.0$ & $142 \pm 5.2^{* *}$ & $99 \pm 7.4^{\#}$ & $106 \pm 6.3^{\# \# \#}$ \\
\hline Cav1 (caveolin-1) & $4279 \pm 675.2$ & $2171 \pm 242.9^{*}$ & $6460 \pm 418.0^{\# \#}$ & $4889 \pm 968.4^{* \#}$ \\
\hline Fgf7 (FGF-7) & $7073 \pm 780.0$ & $5858 \pm 795.5^{*} 0.066$ & $5736 \pm 403.8^{\#}$ & $5306 \pm 958.3$ \\
\hline Ang2 (angiogenin) & $198 \pm 50.5$ & $138 \pm 15.9^{*} 0.085$ & $164 \pm 42.4$ & $131 \pm 6.1$ \\
\hline Vegfb (VEGF-B) & $1637 \pm 107.1$ & $1641 \pm 91.4$ & $2396 \pm 97.9^{\# \# \#}$ & $2195 \pm 246.8^{\#}$ \\
\hline Vegfc (VEGF-C) & $714 \pm 69.2$ & $524 \pm 91.5^{*}$ & $730+111.0$ & $904 \pm 331.3^{\#} 0.089$ \\
\hline Vegfd (VEGF-D) & $791 \pm 50.7$ & $499 \pm 105.6^{*}$ & $1011 \pm 289.9$ & $839 \pm 113.8^{\# \#}$ \\
\hline
\end{tabular}

For last $24 \mathrm{~h}$ cell were incubated in normoxia $(21 \% \mathrm{O})$ or hypoxia $(2 \% \mathrm{O})$.

Means \pm SEM of normalized fluorescence signal. $\mathrm{N}=3$ for each gene, ${ }^{*} p<0.05,{ }^{* *} p<0.01$ WT versus $\mathrm{db} / \mathrm{db},{ }^{*} p<0.05,{ }^{\# \#} p<0.01,{ }^{\# \#} p<0.001$ normoxia versus hypoxia. For $0.05<p<0.1$ exact $p$ values are shown.

in the bone marrow and cultured PACs (Figure 7A,B), to a similar extent as in $\mathrm{db} / \mathrm{db}$ mice. They also had a more proinflammatory phenotype, as illustrated by higher concentrations of sVCAM-1, soluble intercellular adhesion mulecule-1 (sICAM-1), IL-6, and IL-1 $\beta$ in the blood (Figure 7C-F). No differences were found, however, between expressions of genes regulating angiogenic activity (VEGF, KDR, SDF-1, and CXCR4) in PACs isolated form PPAR $\gamma^{+/+}$and PPAR $\gamma^{+/-}$animals (Additional file 4: Figure S3A-D). Also frequency of $\mathrm{CD}_{4} 5^{-} \mathrm{KDR}^{+} \mathrm{Sca}-1^{+}$ endothelial precursors were similar in both groups (Additional file 4: Figure S3E-F). Based on transcriptome analysis of PACs isolated from WT and $\mathrm{db} / \mathrm{db}$ mice we selected a candidate genes to verify effects of PPAR $\gamma$ haplodeficiency and hypoxia on their expression. Cells isolated from $\mathrm{PPAR}^{+/-}$animals did not display 

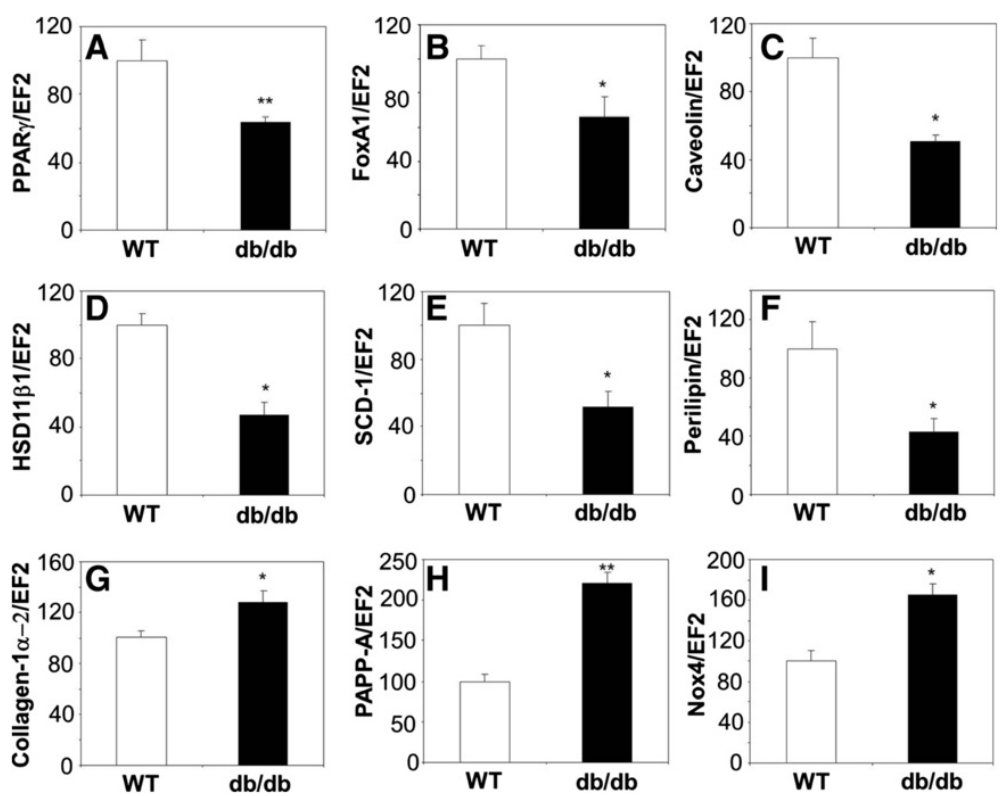

Figure 6 Expression of PPARy associated genes in PACs from diabetic $(\mathrm{db} / \mathrm{db})$ mice, shown as a percentage of gene expression in PACs from wild type (WT) mice. A: PPARY. B: FoxA1. C: caveolin-1. D: HSD11ß. E: SCD-1. F: perilipin. G: collagen-1a. H: PAPP-A. I: Nox4. Quantitative RT-PCR. EF2 serves as an internal control. Each bar represents mean + SEM. $N=3,{ }^{*} p<0.05,{ }^{* *} p<0.01$ versus WT.

different expression levels of pro-oxidative genes (Nox4, p22phox), nor lower levels of cytoprotective genes (GST3, Table 2). Despite lower expression of PPARy in such cells, than in WT ones they were characterized by the same mRNA amount of proinflammatory genes (TNFR-1, P-selectin ligand) and matrix metalloproteinases MMP-2, MMP-9 (Table 2). Similarly, genes associated with proangiogenic properties of PACs (VEGF, SDF-1 and their receptors) were expressed at the same level in $\mathrm{PPAR}^{+/+}$ and PPAR $\gamma^{+/}$cells. However, CAV1 was upregulated in PPAR $^{+/-}$PAC (Table 2).

In earlier experiments we have demonstrated that angiogenesis induced in response to skin injury is impaired in the $\mathrm{db} / \mathrm{db}$ diabetic mice, what is accompanied by defective wound healing [31]. Here we performed similar experiment using PPAR $\gamma^{+/+}$and PPAR $\gamma^{+/-}$animals subjected to full thickness skin excision. Reduced expression of PPAR $\gamma$ influenced neither skin wound closure rate (Figure 8A) nor injury-induced increase in number of capillaries within the wounded tissue (Figure 8B,C).

Then, we compared the efficacy of angiogenesis employing the model of blood flow restoration in $\mathrm{PPAR}^{+/+}$and PPAR $\gamma^{+/-}$animals subjected to hind limb ischemia (Additional file 5: Figure S4A-H). Femoral artery ligation did not affect expression of VEGF in bone marrow or ischemic muscle (Additional file 5: Figure S4A,B), as demonstrated by qRT-PCR analysis performed on day 1 after surgery. In the same time, the expression of SDF-1 did not change significantly in the bone marrow (Additional file 5: Figure $\mathrm{S4C}$ ), but was upregulated in the muscle
(Additional file 5: Figure S4D). The muscular levels of KDR were similar before and one day after artery ligation (Additional file 5: Figure S4E), whereas expression of CXCR4 showed a tendency toward upregulation (Additional file 5: Figure S4F, $p=0.08$ and $p=0.09$ for $\mathrm{PPAR}^{+/+}$and PPAR ${ }^{+/-}$mice, respectively).

We found some differences between genotypes in response to hind limb ischemia. First, untreated PPAR $\gamma^{+/-}$individuals had a higher number of circulating granulocytes, whereas numbers of monocytes and lymphocytes were similar in both experimental groups. One day after femoral artery ligation numbers of monocytes and granulocytes in the peripheral blood decreased significantly in PPAR ${ }^{+/-}$ mice, but remained stable in their wild type counterparts (Figure 9A). This was accompanied by significantly higher leukocytic infiltration of ischemic muscle in the PPAR ${ }^{+/-}$ individuals, observed on day $1^{\text {st }}$ and $14^{\text {th }}$ after artery ligation (Figure 9B). Second, we found more regenerating muscle fibers, with centrally located nuclei, on day $14^{\text {th }}$ after induction of ischemia in mice with lower expression of PPARY (Figure 8C). Nevertheless the restoration of blood flow in ischemic muscle monitored on day $1^{\text {st }}, 7^{\text {th }}$, and $14^{\text {th }}$, as well as number of capillaries counted on day $14^{\text {th }}$ were the same, regardless of PPAR $\gamma$ genotype (Figure 9D,E).

\section{Discussion}

Angiogenic potential of PACs and mature endothelial cells is impaired in $\mathrm{db} / \mathrm{db}$ mice. We demonstrated that it can be restored by activation of PPAR $\gamma$ in cells cultured with rosiglitazone. We also found that diabetes is associated 

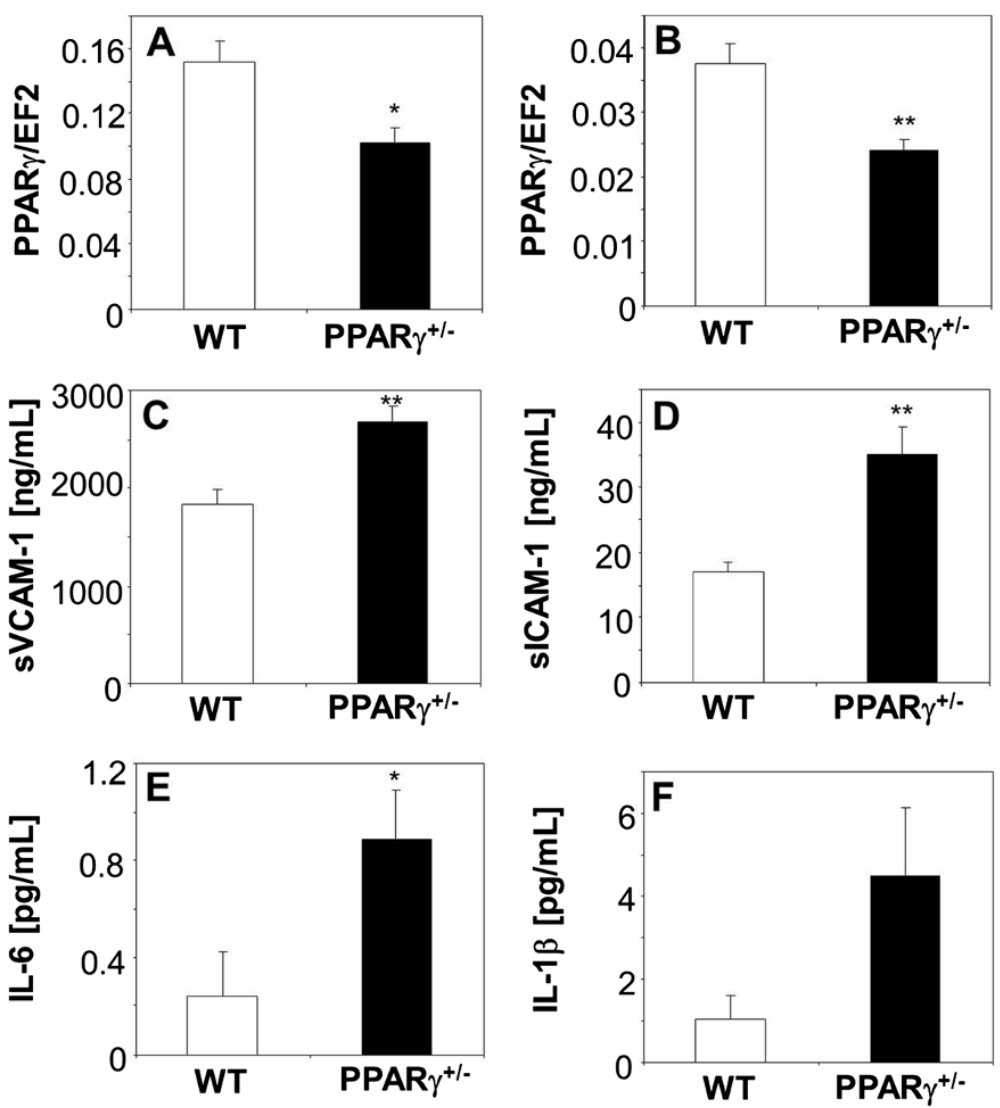

Figure 7 Proinflammatory phenotype of PPARy haplodeficient mice. A-B: Expression of PPARY in wild type (WT) and PPARy heterozygotic $\left(\mathrm{PPAR}^{++-}\right)$mice. A: bone marrow. B: PACs. Quantitative RT-PCR. EF2 serves as an internal control. C-F: Concentration of inflammatory mediators in the blood plasma of WT and PPARY-HT mice. C: sVCAM-1. D: sICAM-1. E: IL-6. F: IL-1ß. Milliplex ${ }^{\oplus}$ MAP platform. Each bar represents mean + SEM. $N=4-6,{ }^{*} p<0.05,{ }^{* *} p<0.01$ versus $W T$.

with reduced expression of PPARy. Thus, one could hypothesize that decreased level of PPAR $\gamma$ may contribute to the inhibition of neovascularization observed in diabetic individuals. Experiments performed in normoglycemic PPAR $\gamma$ haplodeficient mice showed, however, that this is not the case and reduced expression of PPAR $\gamma$ does not affect angiogenesis.

Dysfunction and disturbed angiogenic potential of endothelial cells in diabetes have been comprehensively studied [4]. Much less is known about effect of diabetes on vasculogenic activities of the bone marrow-derived cells. We compared angiogenic potential of PACs, the mononuclear cells isolated from bone marrow of wild type or $\mathrm{db} / \mathrm{db}$ mice and cultured under conditions promoting endothelial differentiation. Our analysis showed that cells derived from $\mathrm{db} / \mathrm{db}$ mice displayed reduced angiogenic capacities. Especially, they demonstrated impaired migration, formation of cord-like structures on Matrigel and capillary outgrowth from spheroids. Only the proliferation rate was not significantly affected. Our results are in accordance with other studies showing decreased angiogenic potential of diabetic EPC isolated both from humans and animals [13-17].
Recently published paper by Li et al., demonstrated that advanced glycation end products (AGE) that are present in diabetes induce EPC apoptosis, impair SDF-1 and NO production [46]. Deleterious effects of diabetes was also reported for mesenchymal stem cells in humans [47].

Transcriptome analysis suggests a reduced capacity of $\mathrm{db} / \mathrm{db}$ PACs to counteract ROS production. The results may also suggest that their impaired migration can be associated with upregulation of integrins accompanied by downregulation of genes involved in filopodia formation, such as efexin or CCT2 [48]. Furthermore, PACs isolated from $\mathrm{db} / \mathrm{db}$ mice showed decreased paracrine potential, what might be related to decreased expression of VEGF-C, VEGF-D, FGF7 or angiogenin.

It has been demonstrated that PPAR $\gamma$ ligands influence angiogenesis, acting generally as proangiogenic agents, and increasing number of bone marrow derived endothelial progenitors. In animal models, such as diabetic rats, treatment with pioglitazone increased density of capillaries in the heart and skeletal muscle by a mechanism unrelated to VEGF-mediated angiogenesis [5]. Proangiogenic effect of pioglitazone, associated with accelerated 
Table 2 Analysis of gene expression in PACs isolated from bone marrow of wild type $\left(\mathrm{PPAR}^{+/+}\right)$or PPARY haplodeficient mice $\left(\right.$ PPAR $^{+/-}$) and cultured in vitro for 9 days

\begin{tabular}{|c|c|c|c|c|}
\hline Gene & Normoxia & & Hypoxia & \\
\hline Oxidative stress and cytoprotection & PPARY $^{+/+}$ & PPAR $^{+/-}$ & PPARY $^{+/+}$ & PPAR $^{+/-}$ \\
\hline Nox4 (NOX4) & $0,00065 \pm 0,00012$ & $0,00090 \pm 0,00016$ & $0,00052 \pm 0,00008$ & $0,00129 \pm 0,00023^{*}$ \\
\hline Cyba (p22phox) & $0,702 \pm 0,102$ & $0,748 \pm 0,094$ & $0,449 \pm 0,077$ & $0,829 \pm 0,185$ \\
\hline Mgst3 (GST III) & $0,043 \pm 0,005$ & $0,060 \pm 0,006^{*}$ & $0,043 \pm 0,004$ & $0,060 \pm 0,005^{*}$ \\
\hline Inflammation & PPARY $^{+/+}$ & PPAR $^{+/-}$ & PPAR $^{+/+}$ & PPAR $^{+/-}$ \\
\hline Tnfrsf1a (TNFR-1) & $0,178 \pm 0,028$ & $0,235 \pm 0,017^{*} 0.092$ & $0,132 \pm 0,015$ & $0,173 \pm 0,012^{*} 0.051^{\# \#}$ \\
\hline Selplg (P-selectin ligand) & $0,00018 \pm 0,00008$ & $0,00021 \pm 0,00005$ & $0,00019 \pm 0,00004$ & $0,00031 \pm 0,00006$ \\
\hline Extracellular matrix remodeling & PPARY $^{+/+}$ & PPAR $^{+/-}$ & PPAR $^{+/+}$ & PPAR $^{+/-}$ \\
\hline Mmp2 (MMP-2) & $0,070 \pm 0,005$ & $0,086 \pm 0,010$ & $0,044 \pm 0,003^{\# \#}$ & $0,101 \pm 0,029^{*} 0.081$ \\
\hline Mmp9 (MMP-9) & $0,416 \pm 0,124$ & $0,194 \pm 0,067$ & $0,263 \pm 0,067$ & $0,148 \pm 0,033$ \\
\hline Migration and proliferation & PPAR $^{+/+}$ & PPAR $^{+/-}$ & PPAR $^{+/+}$ & PPAR $^{+/-}$ \\
\hline Nos3 (NOS3) & $0,00049 \pm 0,00006$ & $0,00063 \pm 0,00013$ & $0,00044 \pm 0,00005$ & $0,00061 \pm 0,00009$ \\
\hline Cav1 (caveolin-1) & $0,051 \pm 0,006$ & $0,080 \pm 0,007^{* *}$ & $0,104 \pm 0,010^{\# \#}$ & $0,162 \pm 0,008^{* * \# \# \#}$ \\
\hline Sdf-1 (CXCL12) & $0,069 \pm 0,021$ & $0,110 \pm 0,022$ & $0,071 \pm 0,022$ & $0,088 \pm 0,010$ \\
\hline Cxcr4 (CXCR-4) & $0,023 \pm 0,007$ & $0,023 \pm 0,004$ & $0,033 \pm 0,006$ & $0,037 \pm 0,004 \#$ \\
\hline Cxcr7 (CXCR-7) & $0,0021 \pm 0,0005$ & $0,0021 \pm 0,0003$ & $0,0095 \pm 0,0020^{\#}$ & $0,0081 \pm 0,0013^{\# \#}$ \\
\hline Vegfa (VEGF-A) & $0,052 \pm 0,005$ & $0,051 \pm 0,005$ & $0,185 \pm 0,047^{\#}$ & $0,164 \pm 0,008^{\# \# \#}$ \\
\hline Flt-1 (VEGFR-1) & $0,00028 \pm 0,00004$ & $0,00038 \pm 0,00011$ & $0,00045 \pm 0,00003^{\#}$ & $0,00065 \pm 0,00019$ \\
\hline KDR (VEGFR-2) & $0,0021 \pm 0,0002$ & $0,0027 \pm 0,0007$ & $0,0013 \pm 0,0005$ & $0,0019 \pm 0,0003$ \\
\hline
\end{tabular}

For last $24 \mathrm{~h}$ cell were incubated in normoxia $\left(21 \% \mathrm{O}_{2}\right)$ or hypoxia $\left(2 \% \mathrm{O}_{2}\right)$. Quantitative RT-PCR, EF2 serves as an internal control. Means $\pm \mathrm{SEM}$. $\mathrm{N}=5-6,{ }^{*} p<0.05$, ${ }^{* *} p<0.01$ PPAR $^{+/+}$versus PPAR ${ }^{+/-},{ }^{\#} p<0.05,{ }^{\# \#} p<0.01,{ }^{\# \# \#} p<0.001$ normoxia versus hypoxia. For $0.05<p<0.1$ exact $p$ values are shown.

healing of ulcers, was also observed in normoglycemic rats [49]. What is more, pioglitazone prevented EPC from apoptosis via PI3K/Akt signaling pathway [50]. Yet another study proved that beneficial effects of PPAR $\gamma$ activation might be also obtained by using other compounds. A dual PPAR $\alpha / \gamma$ agonist, aleglitazar, administrated to mice at a $10 \mathrm{mg} / \mathrm{kg} /$ day dose increased the number and function of circulating angiogenic cells. Furthermore, aleglitazar reduced oxidative stress-induced apoptosis and p53 expression, while phosporylation of eNOS and Akt was elevated [51]. On the other hand, a deleterious effect on EPC biology was demonstrated for too strong PPAR $\gamma$ activation by palmitic acid. Palmitic acid is a natural PPAR $\gamma$ ligand which concentration increases in diabetes leading to impairment of EPC migration and proliferation by PPAR $\gamma$-mediated STAT5 transcription inhibition [52]. Importantly, improved function of EPC and endothelial cells were described in diabetic patients under rosiglitazone therapy $[19,20]$, the effect resulting possibly from reduced generation of ROS and improved bioavailability of NO [19]. In individuals with diabetes it is not easy, however, to discriminate the effects of metabolic correction and direct regulation of angiogenic capacities of endothelial or bone marrow-derived cells.

In our studies, to activate PPAR $\gamma$ in vitro in PACs we used rosiglitazone at the dose of $10 \mu \mathrm{mol} / \mathrm{L}$. As demonstrated by Cox et al., a single oral dose of rosiglitazone $(8 \mathrm{mg})$ in humans leads to a maximal concentration of $603 \mathrm{ng} / \mathrm{mL}(1.69 \mu \mathrm{mol} / \mathrm{L})$ in the plasma [53]. Rosiglitazone is one of three thiazolidinediones introduced in the treatment of type 2 diabetes. Rosiglitazone provided a sustained glycemic control and seemed able to slow down the progression towards T2DM in patients with impaired glucose tolerance [54]. We demonstrated a direct effect of PPAR $\gamma$ activation on PACs angiogenic potential. Incubation of $\mathrm{db} / \mathrm{db}$ PACs with rosiglitazone in vitro, improved their migration, formation of cord-like structures and capillary outgrowth. These effects were probably PPAR $\gamma$-dependent, as were prevented by preincubation of cells with GW9662, PPAR $\gamma$ antagonist. Similar increase in migratory capacities of cultured bone marrow derived cells was observed earlier after treatment with pioglitazone or troglitazone $[21,22,26]$ which may be mediated by reduced expression of ICAM-1 and VCAM-1 adhesion molecules [55]. Beneficial effects of PPAR $\gamma$ activation by rosiglitazone was also proved for vascular smooth muscle cells. Rosiglitazone treatment resulted in increased protein kinase $\mathrm{G}$ activity leading to attenuated hyperplasia after vascular injury [56].

There are, however, studies showing the antiangiogenic activity of PPAR $\gamma$. In fact, in the first report, Murata et al. described a significant decrease in migration and proliferation of choroidal endothelial cells exposed to 


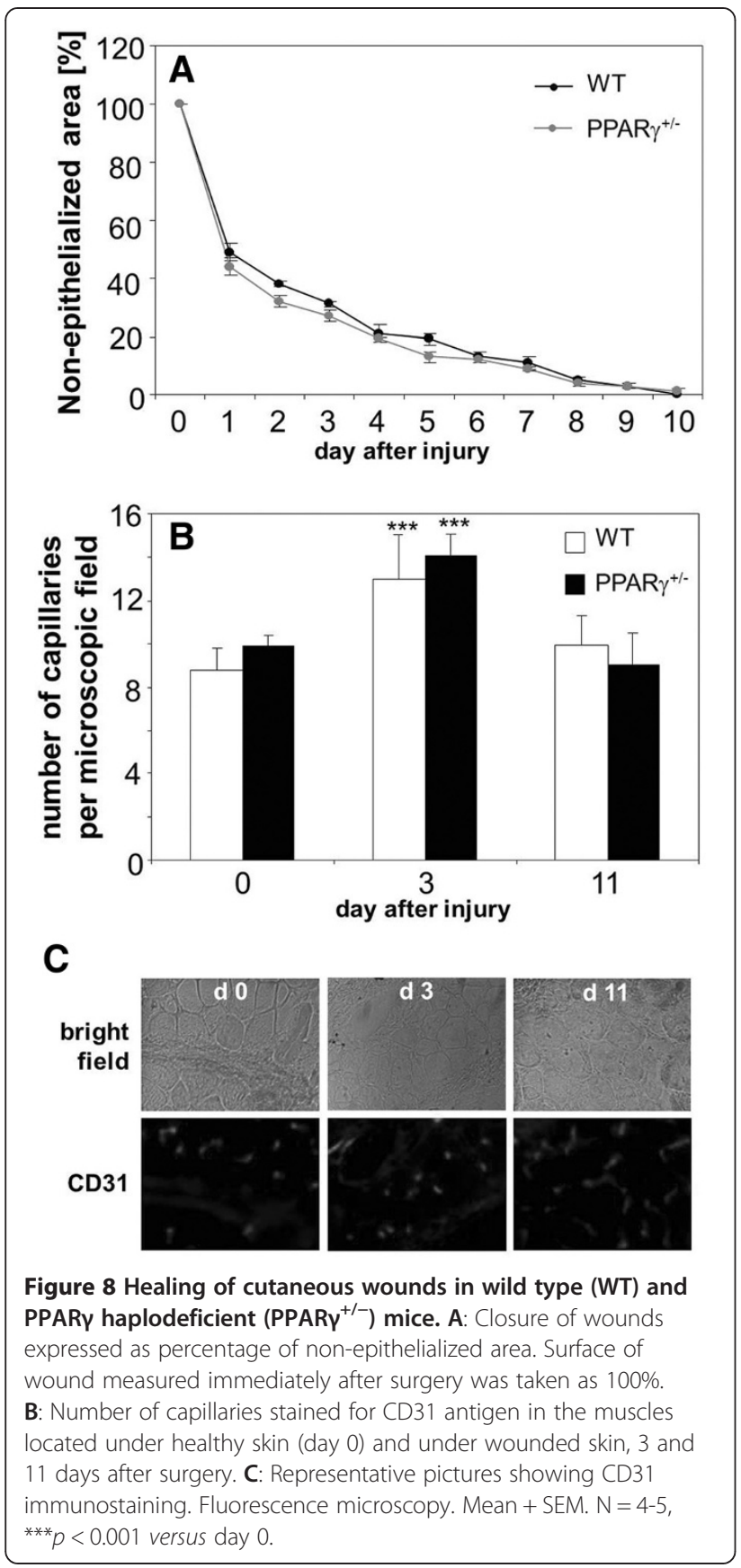

troglitazone or rosiglitazone [57]. Similarly, troglitazone suppressed HUVEC migration, the effect not reversed by GW9662, so possibly independent of PPAR $\gamma$ [27]. Also KR-62980, another PPARy agonist reduced HUVEC migration and formation of cord-like structures on Matrigel, which was accompanied by apoptotic cell death [28]. The reason of such discrepancies are not clear. One can suppose that concentration of PPAR $\gamma$ ligands used in some experiments was high and therefore proapoptotic $[27,28,57]$. Another possibility is that ligands of PPAR $\gamma$ might have different effect on endothelial cells from different vascular beds. The well characterized PPARy target gene is CD36, receptor for antiangiogenic thrombospondin-1 (TSP1), and its upregulation by PPARY agonist may inhibit endothelial functions [58]. CD36 is expressed mainly on microvascular endothelial cells, and at lower level on venous endothelium [59]. Moreover, even in microvasculature the expression of CD36 is organ specific, with the highest level in the heart, muscle and lungs and very low in the bone marrow [60]. One could suppose that such differences may modify the angiogenic response to PPAR $\gamma$ agonists.

We also showed that in vivo administration of rosiglitazone partially restored EPC population in the bone marrow, although not in the peripheral blood. Analysis of gene expression revealed that $\mathrm{db} / \mathrm{db}$ mice have a decreased level of VEGF and unchanged SDF-1 in the bone marrow. In such animals, rosiglitazone showed only a tendency toward upregulation of VEGF, but significantly affected SDF-1. Concentration of SDF-1 protein in the bone marrow increased, while remained unchanged in peripheral blood, thus the gradient of SDF-1 possibly was enhanced. The results were, however, complex: increase in concentration of SDF-1 protein in the bone marrow was not reflected by expression of SDF-1 mRNA, which was even lower after rosiglitazone administration. This suggests that rosiglitazone may influence SDF-1 not primarily at the mRNA level. Similar discrepancy between SDF-1 mRNA and protein expression was observed, for instance, in murine bone marrow after stimulation with granulocyte colony stimulating factor (G-CSF) [61]. Here, the possible mechanism was ascribed to regulation of proteases which are known to degrade SDF-1, such as MMP-9, MMP-2, neutrophil elastase or cathepsin G [60]. Indeed, MMP-9 and MMP-2 are inhibited by PPAR $\gamma$ agonists [27]. Similarly to our finding a decreased expression of SDF-1 was detected in magnetically sorted EPC cells isolated from bone marrow of diabetic mice [62].

Bone marrow derived cells may facilitate angiogenesis, mainly through paracrine effects. Our in vitro experiments revealed that paracrine activity of PACs isolated from $\mathrm{db} / \mathrm{db}$ mice is impaired. Therefore we checked whether the wild type cells may be useful in therapeutic neovascularization and restoration of proper blood perfusion in ischemic muscles of diabetic animals. To this aim we induced hind limb ischemia in $\mathrm{db} / \mathrm{db}$ mice, and then treated them with PACs collected from syngeneic, healthy animals or with conditioned media harvested from such cells. It turned out that a single intramuscular injection of conditioned media facilitates restoration of perfusion. Importantly, delivery of PACs themselves was ineffective, or even detrimental at early time points, what might suggest that a massive death of injected cells 
A

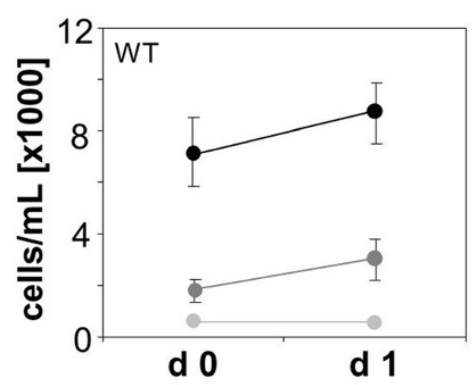

B
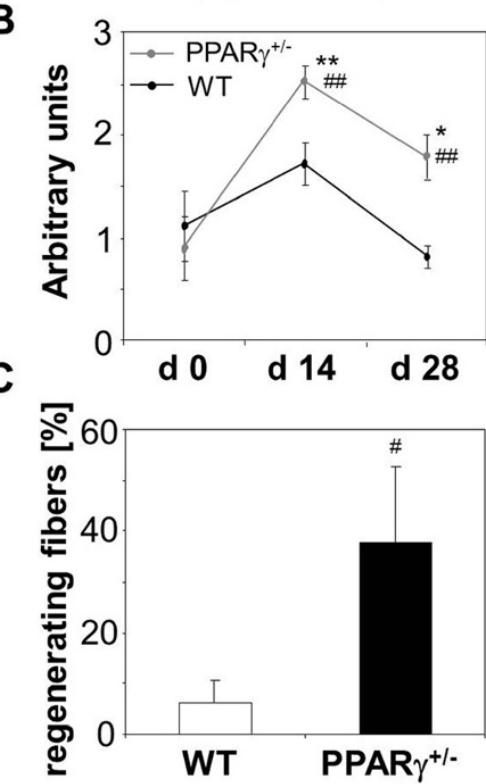

D

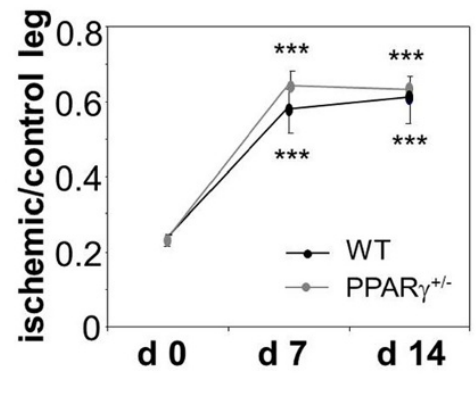

E

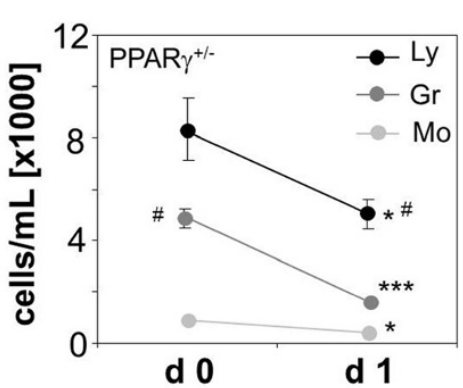

WT

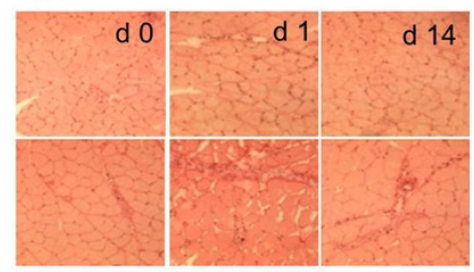

PPAR $\gamma^{+/-}$

WT

PPAR $\gamma^{+/-}$

WT

PPAR $\gamma^{+/-}$

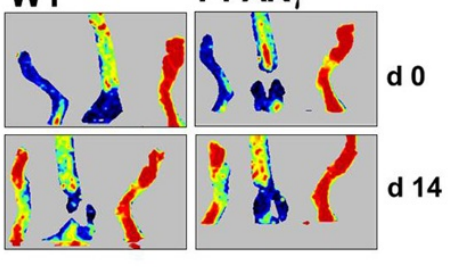

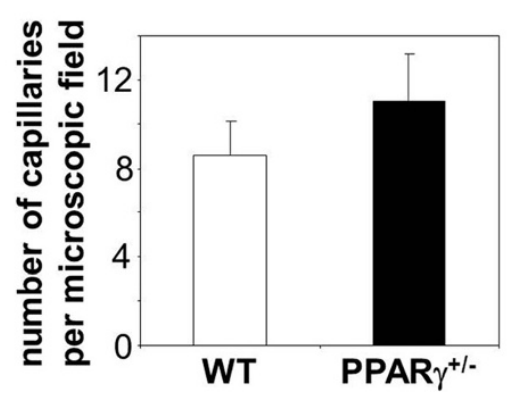

Figure 9 (See legend on next page.) 
(See figure on previous page.)

Figure 9 Effect of induction of hind limb ischemia in wild type (WT) and PPARy haplodeficient (PPAR $\gamma^{+/-}$) mice. A: Number of lymphocytes (Ly), granulocytes (Gr) and monocytes (Mo) in the peripheral blood of WT and PPARY ${ }^{+-}$mice before (d 0) and 1 day (d 1) after surgery. Automated hematology analyzer. B: Leukocytic infiltration of gastrocnemius muscle before (d 0 ) and 14 and 28 days (d 14 and d 28) after surgery. Semiquantitative analysis and representative pictures. Hematoxylin-eosin staining. C: Percentage of regenerating fibers in ischemic muscle, 28 days after surgery. Numerical data and representative picture. Hematoxylin-eosin staining. D: Blood flow expressed as a ratio between ischemic and control leg. Numerical data and representative pictures. Laser-Doppler flowmetry. E: Number of capillaries in the ishcmic muscle, 28 days after surgery. Immunohistochemical staining for CD31. Mean + SEM. $N=5-9(9 A-C, E), N=10(9 D),{ }^{*} p<0.05,{ }^{* *} p<0.01,{ }^{* * *} p<0.001$ versus d 0; ${ }^{*} p<0.05$, $\# p<0.01, \# \# p 0.001$ versus WT.

could induce local inflammatory reaction. The most possible explanation for lack of efficacy of PAC delivery can be a low proportion of cells surviving at the site of transplantation. Recently we showed that after intradermal PAC injection approximately $70 \%$ of cells were removed in first six hours, and less than $1 \%$ were present one week later at the site of delivery [12]. This supposition on too low number of surviving cells can be indirectly supported by results described by Di Santo and colleagues, who showed beneficial, proangiogenic effects of both conditioned media and cells in a rat model of chronic hind limb ischemia. They used, however, serial intramuscular injections (instead of single injection) and higher number of cells $\left(1 \times 10^{6}\right.$ instead of $2.5 \times 10^{5}$ cells $)$ [63]. Our results indicate that cell free conditioned media may be an alternative for therapeutic angiogenesis in ischemic muscles. Beneficial effects of conditioned media from PACs, adipose-derived or bone marrow-derived mesenchymal stem cells have already been described by our and other teams in ischemic muscles in mice and rats $[12,64,65]$.

Analysis of gene expression showed that PACs isolated from $\mathrm{db} / \mathrm{db}$ mice displayed higher VEGFR-2 and lower CXCR4 receptor levels than their wild type counterparts. Incubation of PACs with rosiglitazone did not affect VEGFR-2 and CXCR4 expressions, but upregulated VEGF and $\mathrm{KC}$, both in wild type and $\mathrm{db} / \mathrm{db}$ PACs. These results are in accordance to earlier studies. Transcriptional upregulation of VEGF was first time reported in rat and human vascular smooth muscle cells stimulated in vitro with ciglitazone or rosiglitazone [24,25]. These observations were then confirmed in vascular smooth muscle cells in human atheromatous aortas [66,67]. Moreover, PPAR $\gamma$ activation increased VEGF production in murine adipose tissue [23,68] and cornea [69]. Also in patients with type-2 diabetes the level of VEGF and IL-8 were increased under pioglitazone therapy [70]. Importantly, administration of PPAR $\gamma$ agonists improved revascularization in muscle subjected to hind limb ischemia in mice [71] and enhanced angiogenesis in ischemic brain in rats [32]. Additionally, we noticed that rosiglitazone increased expression of PRG4 and angiotensinogen in cultured PACs. This observation seems interesting as PRG4 can promote development of hemangioblasts
[72] and similar role has been ascribed to the angiotensin converting enzyme [73].

Influence of diabetes on PPAR $\gamma$ expression is not apparent. Direct comparison showed the same levels of PPAR $\gamma$ in adipocytes and aorta of $\mathrm{db} / \mathrm{db}$ (diabetic) and $\mathrm{db} / \mathrm{m}$ (non-diabetic) mice [74]. Analysis performed in rats, where diabetes was induced with streptozotocin (STZ), suggested the tissue specific effects - expression of PPAR $\gamma$ was increased in aorta, but decreased in renal cortex or retina [75]. However, decreased expression of PPAR $\gamma$ can also be expected in diabetic and obese patients, as inverse correlation was found between the body mass index (BMI) and PPARy level in human adipocytes [76]. Noteworthy, PPARY is downregulated by AGE [77] and TNF $\alpha$ [78], overproduced in obesity and type 2 diabetes. Recently, Biscetti et al. described the reduced expression and activity of PPAR $\gamma$ in muscles of STZ-treated diabetic mice subjected to hind limb ischemia. This was accompanied by decreased production of VEGF and impaired neovascularization [69]. In accordance, we found significantly lower level of PPAR $\gamma$ mRNA either in bone marrow or in cultured PACs derived from $\mathrm{db} / \mathrm{db}$ mice. This decrease had possibly a functional effect, as suggested by changes in expression of PPAR $\gamma$ target genes.

One can than suppose that tight regulation of PPAR $\gamma$ expression is necessary for proper angiogenesis. Hence, $\mathrm{PPAR}^{-/}{ }^{-}$mice displayed vasculature defects in placentas, correlated with an unsettled balance of pro- and antiangiogenic factors $[30,45]$. On the other hand, treatment of pregnant wild-type mice with rosiglitazone also resulted in a disorganization of the placental microvasculature [30]. Our results indicate, however, that $\sim 50 \%$ decrease in expression of PPAR $\gamma$ in normoglycemic PPAR $\gamma^{+/-}$mice does not affect angiogenesis in wound healing or hind limb ischemia models. What is more, PACs isolated from $\mathrm{PPAR}^{+/-}$mice do not resemble gene expression pattern observed in diabetic cells. Thus, we assume that similar decrease found in diabetic animals does not contribute to impaired angiogenesis.

In summary, activation of PPAR $\gamma$ with rosiglitazone improves angiogenic potential of PACs and endothelial cells, impaired in diabetes. We showed that expression of PPAR $\gamma$ is decreased in diabetic $\mathrm{db} / \mathrm{db}$ mice, however similar decrease in normoglycemic $\mathrm{PPAR}^{+/-}$mice does 
not affect angiogenesis. This indicate that impaired angiogenic potential in $\mathrm{db} / \mathrm{db}$ mice is independent of decreased expression of PPAR $\gamma$. We showed also that paracrine activity of PACs is sufficient to improve neovascularization in ischemic muscle of diabetic mice. Therefore, application of conditioned media harvested from PACs can be proposed as effective and safe alternative to proangiogenic cell transplantation.

\section{Additional files}

Additional file 1: Supplemental Methods and Results.

Additional file 2: Figure S1. Characterization of PACs isolated from murine bone marrow and cultured in vitro for 10 days. A: Bright field photograph of PACs. Representative picture, magnification $\times 100$. B: Uptake of Dil-AcLDL (red) by PACs. Representative picture, magnification $\times 100$. C: Binding of BS1 lectin (green) by PACs. Representative picture, magnification $\times 100$. D: Formation of cords by PACs stained with Dil-AcLDL (red) and seeded on matrigel. Representative picture, magnification $\times 100$. E: Fraction of cells expressing CD45, KDR, CXCR4 or SCA-1 antigens in PAC populations isolated from wild type (WT) or diabetic (db/db) mice after a 10-day incubation period. Flow cytometry phenotyping. Each bar represents mean $+\mathrm{SEM} . \mathrm{N}=3,{ }^{* *} p<0.01,{ }^{* * *} p<0.001$ versus WT.

Additional file 3: Figure S2. Body mass and blood biochemical parameters in wild type (WT) and diabetic (db/db) mice fed daily for two weeks either with vehicle (WT and $\mathrm{db} / \mathrm{db}$ ) or with rosiglitazone (db/db + ROSI, $10 \mathrm{mg} / \mathrm{kg}$ of body weight) and analyzed 14 days after surgery. A: Body mass before treatment ( $\mathrm{d} 0$ ) and at $14^{\text {th }}$ day of treatment (d 14). B: Concentration of glucose. C: Percentage of glycated hemoglobin. D: Concentration of cholesterol. E: Concentration of triglycerides. Automated biochemistry analyzer. Each bar represents mean + SEM. $N=20,{ }^{* * *} p<0.001$ versus WT, ${ }^{\# \#} p<0.01,{ }^{\# \#} p<0.001$ versus untreated $\mathrm{db} / \mathrm{db},{ }^{\wedge \wedge \wedge} \mathrm{p}<0.001$ versus $\mathrm{d} 0$ ).

Additional file 4: Figure S3. Expression of angiogenic genes in cultured PACs and presence of $C D 45^{-} \mathrm{KDR}^{+} \mathrm{Sca}-1^{+}$cells in bone marrow or peripheral blood of wild type (WT) and PPARy haplodeficient $\left(\mathrm{PPARY}^{+-}\right)$mice. A: VEGF in PACs. B: KDR in PACs. C: SDF-1 in PACs. D: CXCR4 in PACs. Quantitative RT-PCR. EF2 serves as an internal control. E: Percentage of $\mathrm{CD}^{-} 5^{-} \mathrm{KDR}^{+} \mathrm{SCa}-1^{+}$cells in bone marrow. $\mathbf{F}$ : Percentage of $\mathrm{CD} 45^{-} \mathrm{KDR}^{+} \mathrm{SCa}-1^{+}$cells in blood. Multicolor FACS phenotyping. Each bar represents mean + SEM. N = 5-6 (Figure S3 A-D), N = 5-9 (Figure S3 E-F).

Additional file 5: Figure S4. Expression of angiogenic genes in bone marrow and gastrocnemius muscle of wild type (WT) or PPARY haplodeficient (PPARY+/-) mice, untreated (control) or one day after hind limb ischemia (HLI). A: VEGF in bone marrow. B: VEGF in muscle. C: SDF-1 in bone marrow. D: SDF-1 in muscle. E: KDR in bone marrow. F: KDR in muscle. G: CXCR4 in bone marrow. $\mathbf{H}$ : CXCR4 in muscle. Quantitative RT-PCR. EF2 serves as an internal control. Each bar $r$ epresents mean + SEM. N $=5-6,{ }^{*} p<0.05,{ }^{* *} p<0.01,{ }^{* * *} p<0.001$ versus control.

\section{Competing interests}

The authors declare that they have no competing interests.

\section{Authors' contributions}

JK participated in the design of the study and conducted experiments, analyzed data, performed the statistical analysis and wrote draft of the manuscript; AGP, HT, MK, BP, KS have been involved in performing experiments; $A B$ took care of animals; RD provided db/db mice; AJGH analyzed microarray data; AP, LN provided PPARy mice; JD planned experiments and was involved in revising manuscript; AJ conceived of the study, designed and coordinated the study, wrote manuscript. All authors read and approved the final manuscript.

\section{Acknowledgements}

This work was supported by European Union Framework Program POIG 01.02.00-069/09 and Opus project founded by the National Science Center NCN2012/07/B/NZ1/02881. We used also the equipment obtained from EU Framework Programs POIG 02.01.00-12-064/08, and 02.02.00-00-014/08 (to Faculty of Biochemistry, Biophysics and Biotechnology). A.G-P. was a recipient of L'Oreal Poland for Women in Science Scholarship and START Scholarship of Foundation for Polish Science (FNP). K.S. was a recipient of START Scholarship of FNP. L.N. is supported by a grant from the Hungarian Scientific Research Fund (OTKA K100196).

\section{Author details}

'Department of Medical Biotechnology, Krakow, Poland. ${ }^{2}$ Department of Biophysics, Faculty of Biochemistry, Biophysics and Biotechnology, Jagiellonian University, Krakow, Poland. ${ }^{3} \mathrm{R} \& \mathrm{D}$ Department, Adamed Ltd, Pienkow, Poland. ${ }^{4}$ Department of Metabolic Regulation, Institute of Biochemistry, Faculty of Biology, University of Warsaw, Warsaw, Poland. ${ }^{5}$ Department of Molecular Cell Biology and Immunology, VU University Medical Center, Amsterdam, The Netherlands. ${ }^{6}$ Department of Biochemistry and Molecular Biology, Faculty of Medicine, University of Debrecen, Debrecen, Hungary. "MTA-DE "Lendület" Immunogenomics Research Group, University of Debrecen, Debrecen, Hungary. ${ }^{8}$ Sanford-Burnham Medical Research Institute, Orlando, FL, USA. ${ }^{9}$ Department of Molecular Neuropharmacology, Institute of Pharmacology Polish Academy of Science, Krakow, Poland.

Received: 29 July 2014 Accepted: 20 October 2014

Published online: 01 November 2014

\section{References}

1. Lehrke M, Lazar MA: The many faces of PPARgamma. Cell 2005, 123:993-999.

2. Tontonoz P, Spiegelman BM: Fat and beyond: the diverse biology of PPARgamma. Annu Rev Biochem 2008, 77:289-312.

3. Lehmann JM, Moore LB, Smith-Oliver TA, Wilkison WO, Willson TM, Kliewer SA: An antidiabetic thiazolidinedione is a high affinity ligand for peroxisome proliferator-activated receptor gamma (PPAR gamma). J Biol Chem 1995, 270:12953-12956.

4. Giacco F, Brownlee M: Oxidative stress and diabetic complications. Circ Res 2010, 107:1058-1070.

5. Ashoff A, Qadri F, Eggers R, Jöhren O, Raasch W, Dendorfer A: Pioglitazone prevents capillary rarefaction in streptozotocin-diabetic rats independently of glucose control and vascular endothelial growth factor expression. J Vasc Res 2012, 49:260-266.

6. Trepels T, Zeiher AM, Fichtlscherer S: The endothelium and inflammation. Endothel I Endothel Cell Res 2006, 13:423-429.

7. Zampetaki A, Kirton JP, Xu Q: Vascular repair by endothelial progenitor cells. Cardiovasc Res 2008, 78:413-421.

8. Asahara T, Murohara T, Sullivan A, Silver M, van der Zee R, Li T, Witzenbichler B, Schatteman G, Isner JM: Isolation of putative progenitor endothelial cells for angiogenesis. Science 1997, 275:964-967.

9. Grochot-Przeczek A, Dulak J, Jozkowicz A: Therapeutic angiogenesis for revascularization in peripheral artery disease. Gene 2013, 525:220-228.

10. He T, Peterson TE, Katusic ZS: Paracrine mitogenic effect of human endothelial progenitor cells: role of interleukin-8. Am J Physiol Heart Circ Physiol 2005, 289:H968-H972.

11. Urbich C, Aicher A, Heeschen C, Dernbach E, Hofmann WK, Zeiher AM, Dimmeler S: Soluble factors released by endothelial progenitor cells promote migration of endothelial cells and cardiac resident progenitor cells. J Mol Cell Cardiol 2005, 39:733-742.

12. Grochot-Przeczek A, Kotlinowski J, Kozakowska M, Starowicz K, Jagodzinska J, Stachurska A, Volger OL, Bukowska-Strakova K, Florczyk U, Tertil M, Jazwa A, Szade K, Stepniewski J, Loboda A, Horrevoets AJG, Dulak J, Jozkowicz A: Heme oxygenase- 1 is required for angiogenic function of bone marrow-derived progenitor cells: role in therapeutic revascularization. Antioxid Redox Signal 2014, 20:1677-1692.

13. Fadini GP, Sartore S, Schiavon M, Albiero M, Baesso I, Cabrelle A, Agostini C, Avogaro A: Diabetes impairs progenitor cell mobilisation after hindlimb ischaemia-reperfusion injury in rats. Diabetologia 2006, 49:3075-3084.

14. Fadini GP, Miorin M, Facco M, Bonamico S, Baesso I, Grego F, Menegolo M, de Kreutzenberg SV, Tiengo A, Agostini C, Avogaro A: Circulating 
endothelial progenitor cells are reduced in peripheral vascular complications of type 2 diabetes mellitus. J Am Coll Cardiol 2005, 45:1449-1457.

15. Tamarat R, Silvestre J-S, Le Ricousse-Roussanne S, Barateau V, LecomteRaclet L, Clergue M, Duriez M, Tobelem G, Lévy BI: Impairment in ischemiainduced neovascularization in diabetes: bone marrow mononuclear cell dysfunction and therapeutic potential of placenta growth factor treatment. Am J Pathol 2004, 164:457-466.

16. Tepper OM, Galiano RD, Capla JM, Kalka C, Gagne PJ, Jacobowitz GR, Levine JP, Gurtner GC: Human endothelial progenitor cells from type II diabetics exhibit impaired proliferation, adhesion, and incorporation into vascular structures. Circulation 2002, 106:2781-2786.

17. Nowak WN, Borys S, Kusińska K, Bukowska-Strakova K, Witek P, Koblik T, Józkowicz A, Małecki MT, Dulak J: Number of circulating pro-angiogenic cells, growth factor and anti-oxidative gene profiles might be altered in type 2 diabetes with and without diabetic foot syndrome. J Diabetes Investig 2014, 5:99-107.

18. Keats EC, Khan ZA: Vascular stem cells in diabetic complications: evidence for a role in the pathogenesis and the therapeutic promise. Cardiovasc Diabetol 2012, 11:37.

19. Sorrentino SA, Bahlmann FH, Besler C, Müller M, Schulz S, Kirchhoff N, Doerries C, Horváth T, Limbourg A, Limbourg F, Fliser D, Haller H, Drexler H, Landmesser U: Oxidant stress impairs in vivo reendothelialization capacity of endothelial progenitor cells from patients with type 2 diabetes mellitus: restoration by the peroxisome proliferator-activated receptor-gamma agonist rosiglitazone. Circulation 2007, 116:163-173.

20. Pistrosch F, Herbrig K, Oelschlaegel U, Richter S, Passauer J, Fischer S, Gross $P$ : PPARgamma-agonist rosiglitazone increases number and migratory activity of cultured endothelial progenitor cells. Atherosclerosis 2005, 183:163-167.

21. Gensch C, Clever YP, Werner C, Hanhoun M, Böhm M, Laufs U: The PPARgamma agonist pioglitazone increases neoangiogenesis and prevents apoptosis of endothelial progenitor cells. Atherosclerosis 2007, 192:67-74.

22. Werner C, Kamani CH, Gensch C, Böhm M, Laufs U: The peroxisome proliferator-activated receptor-gamma agonist pioglitazone increases number and function of endothelial progenitor cells in patients with coronary artery disease and normal glucose tolerance. Diabetes 2007, 56:2609-2615

23. Gealekman O, Guseva N, Gurav K, Gusev A, Hartigan C, Thompson M, Malkani S, Corvera S: Effect of rosiglitazone on capillary density and angiogenesis in adipose tissue of normoglycaemic humans in a randomised controlled trial. Diabetologia 2012, 55:2794-2799.

24. Jozkowicz A, Dulak J, Piatkowska E, Placha W, Dembinska-Kiec A: Ligands of peroxisome proliferator-activated receptor-gamma increase the generation of vascular endothelial growth factor in vascular smooth muscle cells and in macrophages. Acta Biochim Pol 2000, 47:1147-1157.

25. Yamakawa K, Hosoi M, Koyama H, Tanaka S, Fukumoto S, Morii H, Nishizawa Y: Peroxisome proliferator-activated receptor-gamma agonists increase vascular endothelial growth factor expression in human vascular smooth muscle cells. Biochem Biophys Res Commun 2000, 271:571-574.

26. Fujii M, Inoki I, Saga M, Morikawa N, Arakawa K, Inaba S, Yoshioka K, Konoshita T, Miyamori I: Aldosterone inhibits endothelial morphogenesis and angiogenesis through the downregulation of vascular endothelial growth factor receptor-2 expression subsequent to peroxisome proliferator-activated receptor gamma. J Steroid Biochem Mol Biol 2012, 129:145-152.

27. Park BC, Thapa D, Lee JS, Park S-Y, Kim J-A: Troglitazone inhibits vascular endothelial growth factor-induced angiogenic signaling via suppression of reactive oxygen species production and extracellular signal-regulated kinase phosphorylation in endothelial cells. J Pharmacol Sci 2009, 111:1-12.

28. Kim KY, Ahn JH, Cheon HG: Anti-angiogenic action of PPARY ligand in human umbilical vein endothelial cells is mediated by PTEN upregulation and VEGFR-2 downregulation. Mol Cell Biochem 2011, 358:375-385.

29. McCarthy FP, Drewlo S, English FA, Kingdom J, Johns EJ, Kenny LC, Walsh SK: Evidence implicating peroxisome proliferator-activated receptor- $\gamma$ in the pathogenesis of preeclampsia. Hypertension 2011, 58:882-887.

30. Nadra K, Quignodon L, Sardella C, Joye E, Mucciolo A, Chrast R, Desvergne B: PPARgamma in placental angiogenesis. Endocrinology 2010, 151:4969-4981.

31. Grochot-Przeczek A, Lach R, Mis J, Skrzypek K, Gozdecka M, Sroczynska P, Dubiel M, Rutkowski A, Kozakowska M, Zagorska A, Walczynski J, Was H,
Kotlinowski J, Drukala J, Kurowski K, Kieda C, Herault Y, Dulak J, Jozkowicz A: Heme oxygenase-1 accelerates cutaneous wound healing in mice. PLOS One 2009, 4:e5803

32. Chu K, Lee S-T, Koo J-S, Jung K-H, Kim E-H, Sinn D-I, Kim J-M, Ko S-Y, Kim S-J, Song E-C, Kim M, Roh J-K: Peroxisome proliferator-activated receptor-gamma-agonist, rosiglitazone, promotes angiogenesis after focal cerebral ischemia. Brain Res 2006, 1093:208-218.

33. Scoditti E, Massaro M, Carluccio MA, Distante A, Storelli C, De Caterina R: PPARgamma agonists inhibit angiogenesis by suppressing PKCalphaand CREB-mediated COX-2 expression in the human endothelium. Cardiovasc Res 2010, 86:302-310.

34. Aljada A, O'Connor L, Fu Y-Y, Mousa SA: PPAR gamma ligands, rosiglitazone and pioglitazone, inhibit bFGF- and VEGF-mediated angiogenesis. Angiogenesis 2008, 11:361-367.

35. Kim KY, Cheon HG: Antiangiogenic effect of rosiglitazone is mediated via peroxisome proliferator-activated receptor gamma-activated maxi-K channel opening in human umbilical vein endothelial cells. J Biol Chem 2006, 281:13503-13512.

36. Redondo S, Hristov M, Gümbel D, Tejerina T, Weber C: Biphasic effect of pioglitazone on isolated human endothelial progenitor cells: involvement of peroxisome proliferator-activated receptor-gamma and transforming growth factor-beta1. Thromb Haemost 2007, 97:979-987.

37. Lemay DG, Hwang DH: Genome-wide identification of peroxisome proliferator response elements using integrated computational genomics. J Lipid Res 2006, 47:1583-1587.

38. Varley CL, Bacon EJ, Holder JC, Southgate J: FOXA1 and IRF-1 intermediary transcriptional regulators of PPARgamma-induced urothelial cytodifferentiation. Cell Death Differ 2009, 16:103-114.

39. Hu Q, Zhang X-J, Liu C-X, Wang X-P, Zhang Y: PPARgamma1-induced caveolin-1 enhances cholesterol efflux and attenuates atherosclerosis in apolipoprotein E-deficient mice. J Vasc Res 2010, 47:69-79.

40. Chinetti-Gbaguidi G, Bouhlel MA, Copin C, Duhem C, Derudas B, Neve B, Noel B, Eeckhoute J, Lefebvre P, Seckl JR, Staels B: Peroxisome proliferatoractivated receptor- $\gamma$ activation induces $11 \beta$-hydroxysteroid dehydrogenase type 1 activity in human alternative macrophages. Arterioscler Thromb Vasc Biol 2012, 32:677-685.

41. Morán-Salvador E, López-Parra M, García-Alonso V, Titos E, MartínezClemente M, González-Périz A, López-Vicario C, Barak Y, Arroyo V, Clària J: Role for PPARY in obesity-induced hepatic steatosis as determined by hepatocyte- and macrophage-specific conditional knockouts. FASEB J Off Publ Fed Am Soc Exp Biol 2011, 25:2538-2550.

42. Nagai S, Shimizu C, Umetsu M, Taniguchi S, Endo M, Miyoshi H, Yoshioka N, Kubo M, Koike T: Identification of a functional peroxisome proliferatoractivated receptor responsive element within the murine perilipin gene. Endocrinology 2004, 145:2346-2356.

43. Handschuh K, Guibourdenche J, Guesnon M, Laurendeau I, Evain-Brion D, Fournier T: Modulation of PAPP-A expression by PPARgamma in human first trimester trophoblast. Placenta 2006, 27(Suppl A):S127-S134.

44. Ghosh AK, Bhattacharyya S, Wei J, Kim S, Barak Y, Mori Y, Varga J: Peroxisome proliferator-activated receptor-gamma abrogates Smaddependent collagen stimulation by targeting the p300 transcriptional coactivator. FASEB J Off Publ Fed Am Soc Exp Biol 2009, 23:2968-2977.

45. Barak Y, Nelson MC, Ong ES, Jones YZ, Ruiz-Lozano P, Chien KR, Koder A, Evans RM: PPAR gamma is required for placental, cardiac, and adipose tissue development. Mol Cell 1999, 4:585-595.

46. Li H, Zhang X, Guan X, Cui X, Wang Y, Chu H, Cheng M: Advanced glycation end products impair the migration, adhesion and secretion potentials of late endothelial progenitor cells. Cardiovasc Diabeto/ 2012, 11:46.

47. Liu Y, Li Z, Liu T, Xue X, Jiang H, Huang J, Wang H: Impaired cardioprotective function of transplantation of mesenchymal stem cells from patients with diabetes mellitus to rats with experimentally induced myocardial infarction. Cardiovasc Diabetol 2013, 12:40.

48. Kirfel G, Rigort A, Borm B, Herzog V: Cell migration: mechanisms of rear detachment and the formation of migration tracks. Eur J Cell Biol 2004, 83:717-724

49. Brzozowski T, Konturek PC, Pajdo R, Kwiecień SN, Konturek S, Targosz A, Burnat G, Cieszkowski J, Pawlik WW, Hahn EG: Agonist of peroxisome proliferator-activated receptor gamma (PPAR-gamma): a new compound with potent gastroprotective and ulcer healing properties. Inflammopharmacology 2005, 13:317-330. 
50. Zhang H-F, Wang L, Yuan H-J, Ma Y-H, Wang Y-F, Hu Z-Y, Su Y, Zhao Z-G: PPAR- $\gamma$ agonist pioglitazone prevents apoptosis of endothelial progenitor cells from rat bone marrow. Cell Biol Int 2013, 37:430-435.

51. Werner CM, Schirmer SH, Gensch C, Pavlickova V, Pöss J, Wright MB, Böhm M, Laufs U: The dual PPARa/Y agonist aleglitazar increases the number and function of endothelial progenitor cells: implications for vascular function and atherogenesis. Br J Pharmacol 2014, 171:2685-2703.

52. Trombetta A, Togliatto G, Rosso A, Dentelli P, Olgasi C, Cotogni P, Brizzi MF Increase of palmitic acid concentration impairs endothelial progenitor cell and bone marrow-derived progenitor cell bioavailability: role of the STAT5/PPARy transcriptional complex. Diabetes 2013, 62:1245-1257.

53. Cox PJ, Ryan DA, Hollis FJ, Harris AM, Miller AK, Vousden M, Cowley H: Absorption, disposition, and metabolism of rosiglitazone, a potent thiazolidinedione insulin sensitizer, in humans. Drug Metab Dispos Biol Fate Chem 2000, 28:772-780.

54. Consoli A, Formoso G: Do thiazolidinediones still have a role in treatment of type 2 diabetes mellitus? Diabetes Obes Metab 2013, 15:967-977.

55. Spigoni V, Picconi A, Cito M, Ridolfi V, Bonomini S, Casali C, Zavaroni I, Gnudi L, Metra M, Dei Cas A: Pioglitazone improves in vitro viability and function of endothelial progenitor cells from individuals with impaired glucose tolerance. PLoS One 2012, 7:e48283.

56. Yang H-M, Kim B-K, Kim J-Y, Kwon Y-W, Jin S, Lee J-E, Cho H-J, Lee H-Y, Kang $\mathrm{H}-J$, Oh B-H, Park Y-B, Kim H-S: PPARy modulates vascular smooth muscle cell phenotype via a protein kinase G-dependent pathway and reduces neointimal hyperplasia after vascular injury. Exp Mol Med 2013, 45:e65.

57. Murata T, He S, Hangai M, Ishibashi T, Xi XP, Kim S, Hsueh WA, Ryan SJ, Law RE, Hinton DR: Peroxisome proliferator-activated receptor-gamma ligands inhibit choroidal neovascularization. Invest Ophthalmol Vis Sci 2000, 41:2309-2317.

58. Huang H, Campbell SC, Bedford DF, Nelius T, Veliceasa D, Shroff EH, Henkin J, Schneider A, Bouck N, Volpert OV: Peroxisome proliferator-activated receptor gamma ligands improve the antitumor efficacy of thrombospondin peptide ABT510. Mol Cancer Res MCR 2004, 2:541-550.

59. Chi J-T, Chang HY, Haraldsen G, Jahnsen FL, Troyanskaya OG, Chang DS, Wang Z, Rockson SG, van de Rijn M, Botstein D, Brown PO: Endothelial cell diversity revealed by global expression profiling. Proc Natl Acad Sci U S A 2003, 100:10623-10628.

60. Nolan DJ, Ginsberg M, Israely E, Palikuqi B, Poulos MG, James D, Ding B-S, Schachterle W, Liu Y, Rosenwaks Z, Butler JM, Xiang J, Rafii A, Shido K, Rabbany SY, Elemento O, Rafii S: Molecular signatures of tissue-specific microvascular endothelial cell heterogeneity in organ maintenance and regeneration. Dev Cell 2013, 26:204-219.

61. Jin F, Zhai Q, Qiu L, Meng H, Zou D, Wang Y, Li Q, Yu Z, Han J, Li Q, Zhou B: Degradation of BM SDF-1 by MMP-9: the role in G-CSF-induced hematopoietic stem/progenitor cell mobilization. Bone Marrow Transplant 2008, 42:581-588.

62. Barthelmes D, Zhu L, Shen W, Gillies MC, Irhimeh MR: Differential gene expression in Lin-/VEGF-R2+ bone marrow-derived endothelial progenitor cells isolated from diabetic mice. Cardiovasc Diabeto/ 2014, $13: 42$

63. Di Santo S, Yang Z, Wyler Von Ballmoos M, Voelzmann J, Diehm N Baumgartner I, Kalka C: Novel cell-free strategy for therapeutic angiogenesis: in vitro generated conditioned medium can replace progenitor cell transplantation. PLoS One 2009, 4:e5643.

64. Kinnaird T, Stabile E, Burnett MS, Lee CW, Barr S, Fuchs S, Epstein SE: Marrow-derived stromal cells express genes encoding a broad spectrum of arteriogenic cytokines and promote in vitro and in vivo arteriogenesis through paracrine mechanisms. Circ Res 2004, 94:678-685

65. Madonna R, Pizzi SD, Tartaro A, De Caterina R: Transplantation of mesenchymal cells improves peripheral limb ischemia in diabetic rats. Mol Biotechnol 2014, 56:438-448.

66. Ho-Tin-Noé B, Le Dall J, Gomez D, Louedec L, Vranckx R, El-Bouchtaoui M, Legrès L, Meilhac $O$, Michel J-B: Early atheroma-derived agonists of peroxisome proliferator-activated receptor- $\gamma$ trigger intramedial angiogenesis in a smooth muscle cell-dependent manner. Circ Res 2011 109:1003-1014

67. Michel J-B, Martin-Ventura JL, Nicoletti A, Ho-Tin-Noé B: Pathology of human plaque vulnerability: mechanisms and consequences of intraplaque haemorrhages. Atherosclerosis 2014, 234:311-319.
68. Michailidou Z, Turban S, Miller E, Zou X, Schrader J, Ratcliffe PJ, Hadoke PWF, Walker BR, Iredale JP, Morton NM, Seckl JR: Increased angiogenesis protects against adipose hypoxia and fibrosis in metabolic diseaseresistant 11ß-hydroxysteroid dehydrogenase type 1 (HSD1)-deficient mice. J Biol Chem 2012, 287:4188-4197.

69. Biscetti F, Pecorini G, Arena V Stigliano E, Angelini F, Ghirlanda G, Ferraccioli $G$, Flex A: Cilostazol improves the response to ischemia in diabetic mice by a mechanism dependent on PPARy. Mol Cell Endocrinol 2013, 381:80-87.

70. Vijay SK, Mishra M, Kumar H, Tripathi K: Effect of pioglitazone and rosiglitazone on mediators of endothelial dysfunction, markers of angiogenesis and inflammatory cytokines in type-2 diabetes. Acta Diabetol 2009, 46:27-33.

71. Huang P-H, Sata M, Nishimatsu H, Sumi M, Hirata Y, Nagai R: Pioglitazone ameliorates endothelial dysfunction and restores ischemia-induced angiogenesis in diabetic mice. Biomed Pharmacother Bioméd Pharmacothér 2008, 62:46-52.

72. Liu YJ, Lu SH, Xu B, Yang RC, Ren Q, Liu B, Li B, Lu M, Yan FY, Han ZB, Han $Z C$ : Hemangiopoietin, a novel human growth factor for the primitive cells of both hematopoietic and endothelial cell lineages. Blood 2004, 103:4449-4456.

73. Zambidis ET, Park TS, Yu W, Tam A, Levine M, Yuan X, Pryzhkova M, Péault $B$ : Expression of angiotensin-converting enzyme (CD143) identifies and regulates primitive hemangioblasts derived from human pluripotent stem cells. Blood 2008, 112:3601-3614.

74. Seto SW, Lam TY, Leung GPH, Au ALS, Ngai SM, Chan SW, Kwan YW: Comparison of vascular relaxation, lipolysis and glucose uptake by peroxisome proliferator-activated receptor-gamma activation in $+\mathrm{db} /+\mathrm{m}$ and + db/+db mice. Eur J Pharmacol 2007, 572:40-48.

75. Wang F, Gao L, Gong B, Hu J, Li M, Guan Q, Zhao J: Tissue-specific expression of PPAR mRNAs in diabetic rats and divergent effects of cilostazol. Can J Physiol Pharmacol 2008, 86:465-471.

76. Montague CT, Prins JB, Sanders L, Zhang J, Sewter CP, Digby J, Byrne CD, O'Rahilly S: Depot-related gene expression in human subcutaneous and omental adipocytes. Diabetes 1998, 47:1384-1391.

77. Chello M, Spadaccio C, Lusini M, Covino E, Blarzino C, De Marco F, Di Domenico F, Coccia R: Advanced glycation end products in diabetic patients with optimized glycaemic control and their effects on endothelial reactivity: possible implications in venous graft failure. Diabetes Metab Res Rev 2009, 25:420-426.

78. Itoh H, Doi K, Tanaka T, Fukunaga $Y$, Hosoda K, Inoue G, Nishimura H, Yoshimasa Y, Yamori Y, Nakao K: Hypertension and insulin resistance: role of peroxisome proliferator-activated receptor gamma. Clin Exp Pharmacol Physiol 1999, 26:558-560.

doi:10.1186/s12933-014-0150-7

Cite this article as: Kotlinowski et al:: PPARy activation but not PPARY haplodeficiency affects proangiogenic potential of endothelial cells and bone marrow-derived progenitors. Cardiovascular Diabetology 2014 13:150

\section{Submit your next manuscript to BioMed Central and take full advantage of:}

- Convenient online submission

- Thorough peer review

- No space constraints or color figure charges

- Immediate publication on acceptance

- Inclusion in PubMed, CAS, Scopus and Google Scholar

- Research which is freely available for redistribution 